(Department of Zoology, University of Michigan.)

\title{
CONTRIBUTIONS ON THE DEVELOPMENT OF THE REPRODUCTIVE SYSTEM IN THE MUSK TURTLE, STERNOTHERUS ODORATUS (LATREILLE).
}

II. GONADOGENESIS AND SEX DIFFERENTIATION ${ }^{1}$.

By

Paul L. Risley.

With 41 figures in the text.

(Eingegangen am 5. Januar 1933.)

Table of Contents. page

I. Introduction . . . . . . . . . . . . . . . . . . . . 4493

II. Materials and methods . . . . . . . . . . . . . . . . . . . . . 494

III. Observations . . . . . . . . . . . . . . . . . . . . . 495

A. The undifferentiated or indifferent gonads . . . . . . . . . . .495

B. The development of cortex and medulla (The bisexual or indeterminate gonads) . . . . . . . . . . . . . . . . . . 501

C. Sex differentiation . . . . . . . . . . . . . . . . . . . . . . 509

1. Macroscopic observations . . . . . . . . . . . . . . . 509

2. Microscopic observations . . . . . . . . . . . . . 515

a) The development of the ovary . . . . . . . . . . 515

b) The development of the testis . . . . . . . . . . . 519

c) Sex reversal ...................523

IV. Literature and discussion . . . . . . . . . . . . . . . 525

V. Summary and conclusions . . . . . . . . . . . . . . . . 538

VI. Literature cited . . . . . . . . . . . . . . . . . . . 540

\section{Introduction.}

In the previous contribution (1933) of this series, I followed the embryonic origin and migration of the primordial germ cells from an extraregional position in the posterior and lateral margins of the area pellucida to a resident location in the undifferentiated germ glands. In this paper, the investigation of the problem of the embryonic history of the germ cells is extended to include the problems of gonadogenesis and sex differentiation, which are concerned directly with the development of the male and female sex organs of the musk turtle, Sternotherus odoratus (LATREHLE).

\footnotetext{
${ }^{1}$ Contribution from the Zoological Laboratory, University of Michigan.
} 
The occurrence of such phenomena as intersexuality and sex reversal in higher forms demands that the embryogenesis of the sex organs be clearly understood before constructive interpretations of the abnormalities can be attempted, and before exceptional cases can be assigned definitely as due to factors other than developmental. In fact, many attempts have been made to account for the existence of intersexual adults and sex reversals, especially among the avian and mammalian forms, by assuming that they are the result of an anomalous development. These explanations are founded, however, principally upon the probability of the occurrence of certain histogenetic processes which are not represented in the factual evidence furnished by descriptive embryology. An examination of the literature reveals an obvious need for further investigations of gonadogenesis and sex differentiation in other forms than the chick, the rat, the mouse, and the usual laboratory animals. Furthermore, the literature is replete with many conflicting statements of what is, in all probability, one and the same story, but manifested in diverse ways because of the different histological pictures which are presented in various animal types. Since practically nothing is known regarding sex problems and the development of the sex organs in reptiles, it is hoped that the results recorded here will aid in filling the large gap which exists in our knowledge of the morphology of sex differentiation in vertebrate organisms.

I wish to express my appreciation to Professor Peter Okkelberk of the Department of Zoology of the University of Michigan for his constant inspiration, guidance, and criticisms during this study.

\section{Material and methods.}

The materials used in this study consist of a complete series of embryos of Sternotherus odoratus L., ranging from the time of the earliest appearance of the carapace up to the time of hatching. The embryos were obtained from eggs collected in the latter part of June. The eggs were kept in the laboratory and young individuals hatched usually between the 65th and 75th days of incubation. Approximately 350 individuals have been examined.

The younger embryos of the series were opened along the mid-ventral line to allow rapid penetration of the fixing agent, which was in all cases BouIN's fluid. Only the trunk parts and the cloacal region were sectioned for microscopic examination. In the intermediate and later stages (from those embryos with a carapace of $8.0 \mathrm{~mm}$. in length to those taken at hatching), the plastron, alimentary tract, and the parts anterior to the nephroi were removed prior to fixation. The urogenital system was dissected away from the pelvis and carapace after fixation, and sectioned at 8 or at 10 micra. HeIdenhaIx's Iron Haematoxylin alone or followed by a counterstain of Eosin was employed in staining. 
Because of the fact that considerable variation in detail is encountered in specimens of the same carapace length as measured in a straight mid-sagittal line, the specimens have been placed in representative groups for descriptive convenience. This seems to be the most satisfactory way to treat the variables met with in the arrangement of the embryonic stages, which are summarized in table I.

Table I. Embryonic stages correlated with size and age of embryos with statement of degree of gonadal differentiation.

\begin{tabular}{|c|c|c|}
\hline Embryonale stage & Approximale age & Degres of differentiation \\
\hline 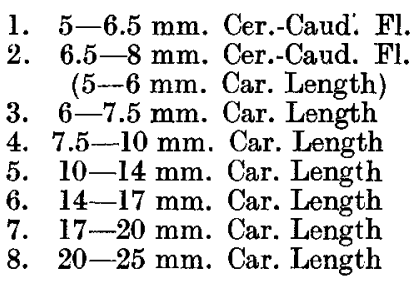 & $\begin{array}{c}14-17 \text { days } \\
18-21 \text { days } \\
\\
21-25 \text { days } \\
25-32 \text { days } \\
33-40 \text { days } \\
41-50 \text { days } \\
51-60 \text { days } \\
60 \text { days to hatching }\end{array}$ & $\begin{array}{c}\text { Genital ridge } \\
\text { Indifferent gonads } \\
\\
\text { Indifferent gonads } \\
\text { Indeterminate gonads } \\
\text { Indeterminate gonads } \\
\text { Sex differentiation } \\
\text { Sex differentiation } \\
\text { Sex differentiation }\end{array}$ \\
\hline
\end{tabular}

\section{Observations.}

\section{A. The undifferentiated or indifferent gonads.}

Embryos of 5.0 to $6.5 \mathrm{~mm}$. (cervical-caudal flexure) length. - In $5.0 \mathrm{~mm}$. embryos, each genital ridge may be recognized as a thickened portion of the peritoneum which covers the ventro-median surface of the mesonephros. The ridges extend from the tenth or eleventh MaLPIGHIan corpuscles of the mesonephroi posteriorly almost to the caudal ends of the mesonephric bodies. The peritoneum is two or three cells deep and contains one or several primordial germ cells which have entered this region from the entoderm via the mesentery (see fig. 17, RISLEY, 1933). Immediately below the epithelium a thin sheet of mesenchyme stands between the peritoneum and the expanding mesonephric blood vessels. In the anterior part of the ridges, where the primordial germ cells are infrequent but occasionally present, there are pronounced irregularities in the epithelial surfaces, and cords of cells are proliferating dorso-medially towards the growing adrenal glands (fig. 1). These cords are the fundaments of the rete-cords and probably are produced from the germinal epithelium. In their course, they pass close by the developing MaLPIGHian corpuscles and in a slightly later stage establish a direct contact with them. This connection is brought about mainly through the general growth of the region and by no such means as a direct outgrowth of cells from either the "funnel cord" of ALLEN (1905), who applied this term to the early rete-cord because of its attachment to the peritoneum at the vestigial peritoneal funnel of the early MALPIGHIan corpuscle of the mesonephros, or from the MaLPIGHran corpuscle itself. 


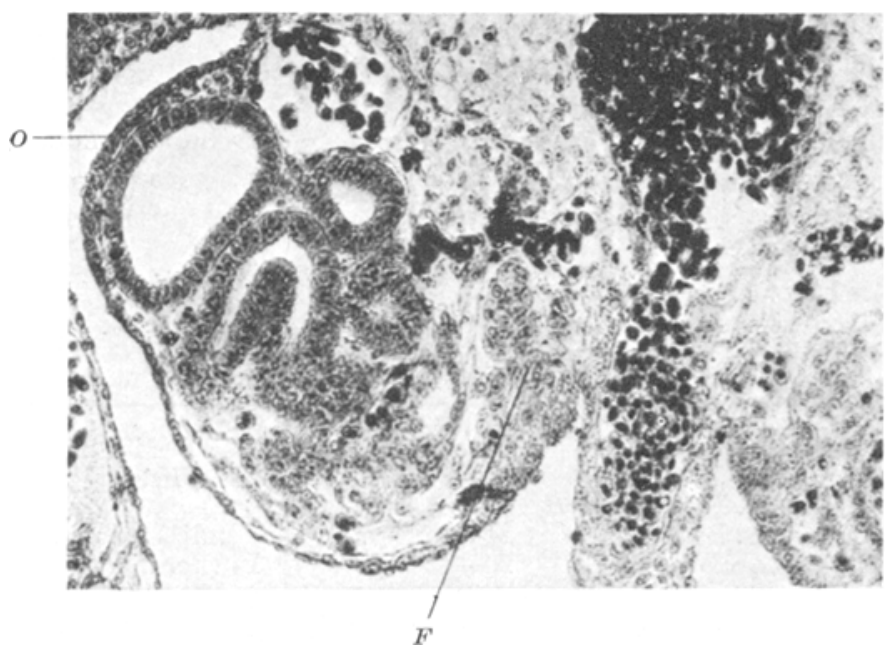

Fig. 1. Transverse section through the anterior end of the genital ridge of an embryo of $5.0 \mathrm{~mm}$. (C. -C. F.), showing the origin of the early funnel-cord and its relations to the germinal epithelium, the developing mesonephric corpuscle and the adrenal fundament. $F$ "funnel cord" of ALIEN. $O$ Oviducal ridge. $(\times 220$.

In fact, the capsules of the corpuscles are so close to the genital ridge that they are almost in contact with it (figs. $2,3,4$ ). The general orientation of

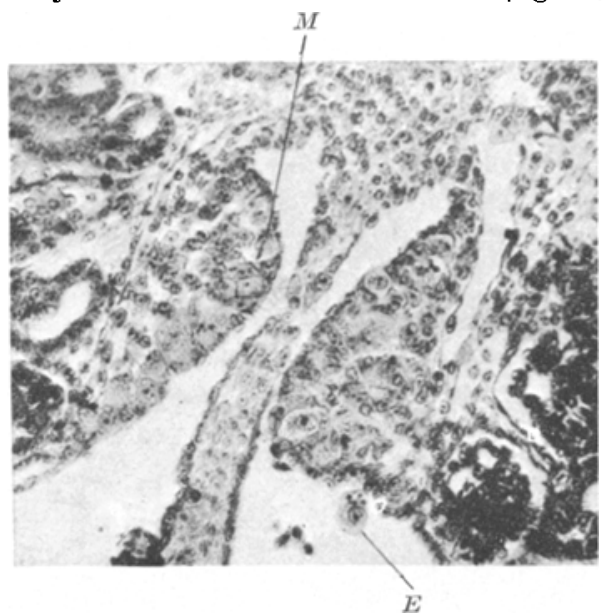

Fig. 2. Transverse section through the genital ridges of an embryo of $6.0 \mathrm{~mm}$. (C. - C. F.) Note the indefiniteness of the epithelial layer and the crowded active appearance of the epithelial tissue. $M$ primordial germ cell in mitosis. $E$ primordial germ cell in coelom. $(\times 220$. the cells of the cords give the distinct impression that the cells are of epithelial origin and that they are moving away from the peritoneum. There is no indication in the stages examined that the retecord fundaments originate through a condensation of the mesenchyme of the nephric region. The entire question of rete-cord formation is so closely interrelated with the dev lopment of the mesonephroi and the adrenal glands that further details can not be presented here. It is of interest to note that they are laid down early in the history of the genital ridge at the expense of the epithelium.

During this period of development, the genital ridge increaws in size by the addition of new cells. Some of these are primordial germ 
cells which are entering the region somewhat tardily and which may enter the epithelial layer or immediately beneath it. The entire gonadal swelling is not more than five or six cells deep, and its main constituents are epithelial cells which leave the main body of the epithelial layer for a deeper position (fig. 2). Mesenchymal elements are rare indeed and the entire ridge is of a darker tinge which supports the contention that the deeper cells are of an epithelial origin. The peritoneal cells are dividing rapidly and the oval nuclei of the cells project out from the peritoneum as if the cells were breaking away. At certain favorable

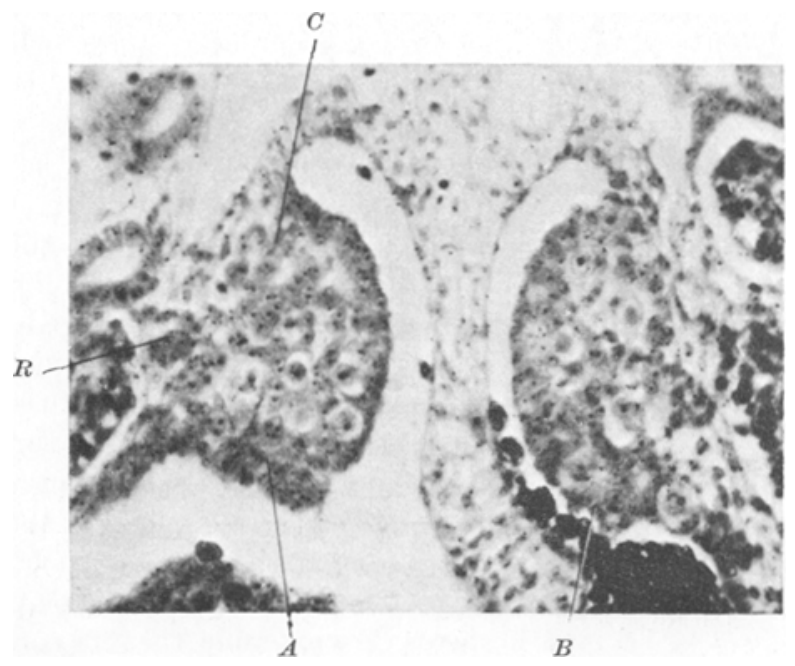

Fig. 3. Transection through the genital ridges of an embryo of $6.5 \mathrm{~mm}$. (C. -C. F.) Mesenchymal elements are infrequent and the gonad is relatively unorganized and blastemaI in character. The epitbelium is actively proliferating at $A$ and $B$. A group of cells is attached to the epithelium at $C . R$ rete-cord. $(\times 220$.)

locations, there are evidences of a direct streaming of cells from the surface layers adjacent to the coelom toward the inner parts (fig. 3). In embryos of $6.5 \mathrm{~mm}$. length (C.-C. F.), the genital ridge is an unorganized mass of primordial germ cells and epithelial elements with a minimum of mesenchymal tissue. The epithelial layer itself can be distinguished. only by the more compact arrangement of its cellular constituents, since a basement membrane is not evident. Only the primordial germ cells have distinct cell membranes and the remainder of the cells appear to be merged as a syncytium.

Embryos of 6.5 to $8.0 \mathrm{~mm}$. length (C.-C. F., Carapace length $=4.0$ to $5.0 \mathrm{~mm}$.). The gonads of these embryos show very little change other than that of general growth. There is an increased number of both epithelial and primordial germ cells, which are dividing rapidly to produce an outpushing of the gonad into the coelomic cavity (fig. 4). The 
gonads are now 1.0 to $1.1 \mathrm{~mm}$. in length, and there are no appreciable differences in the relative sizes and positions of the gonads on the right and left sides. Epithelial cells continue to break away from the epithelium to enter the inner part of the gonad. Very often they flatten themselves about a primordial germ cell to form a follicular likeness. They segregate themselves from the epithelial layer either singly or in

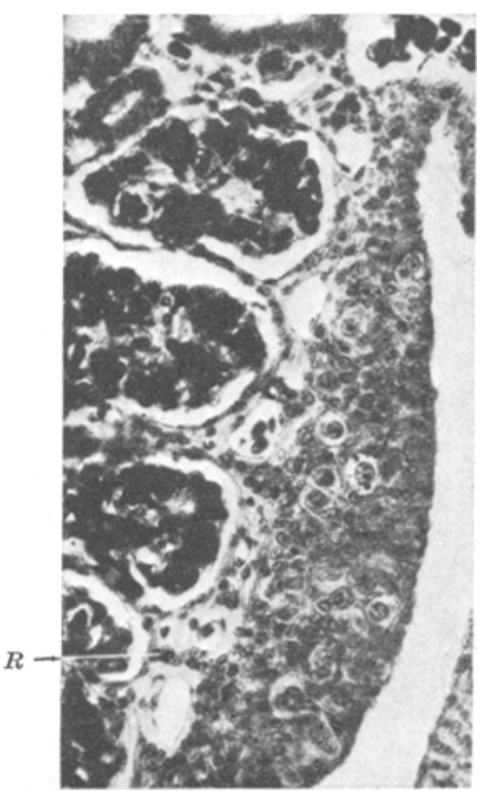

Fig. 4. A longitudinal section through an indifferent gonad of an embryo of $7.5 \mathrm{~mm}$. (C. - C. F.) The gonadis unorganized and the rete-connections are established. The capsules of the mesonephros are very close to the base of the gonads. A primordial germ cell still contains yolk granules. $(\times 220$. groups which sometimes contain primordial germ cells. The rete-cords retain their attachments to the epithelium at the point of origin and itis not unusual to find a primordial germ cell or two within the gonadal parts of the cords. These parts are destined to be sex-cords or medullary cords (fig. 6).

Embryos of 6.0 to $7.5 \mathrm{~mm}$. Carapace length. The specimens of this period show definitely the transition of the gonad from a more or less disarranged blastema of epithelial and primordial germ cells to a properly organized indifferent sex-gland. The two most important features to be considered are the development of the sexcords and the development of the stromal tissue. The fundaments of both have been laid down partially in the preceding stages. For example, the rete-cord attachment to the epithelium marked a locus for the further proliferation and entrance of epithelial and germ cells to the central part of the gonad. The portion within the gonad proper is sex-cord, while the rete-cord extends from the base of the gonad to a MaLPighian corpuscle. No lumen is present in the cord, but a marked indentation at the site of attachment suggests a true invagination and ingrowth of the epithelium. At other sites, like indentations and the elongated and crowded character of the cells betray the fact that cords of cells are growing out of the epithelium inwards. Primordial germ cells also migrate inwards with the epithelial cells as a cord-like structure (fig. 5), and the result is a sex-cord, which later transforms into a seminiferous tubule of the testis, or a medullary cord, doomed to degeneration in the ovary. The sex-cords are made up of epithelial and primordial germ cells and retain this organization throughout their subsequent history. 
The differentiation of the stroma aids greatly in demonstrating the true origin of the sex-cords. The similar nature of all of the somatic cells of the genital ridge and the absence of basement membranes make the problem of the origin of the sex-cords a difficult one. However, a few of the cells of this complex become elongated and take a lighter stain. They appear to flatten out around groups of primordial germ cells and other epithalial cells. Two or three of the lighter cells may appear between two similar groups. Some of them form a flattened basement membrane around the groups of epithelial cells which surround

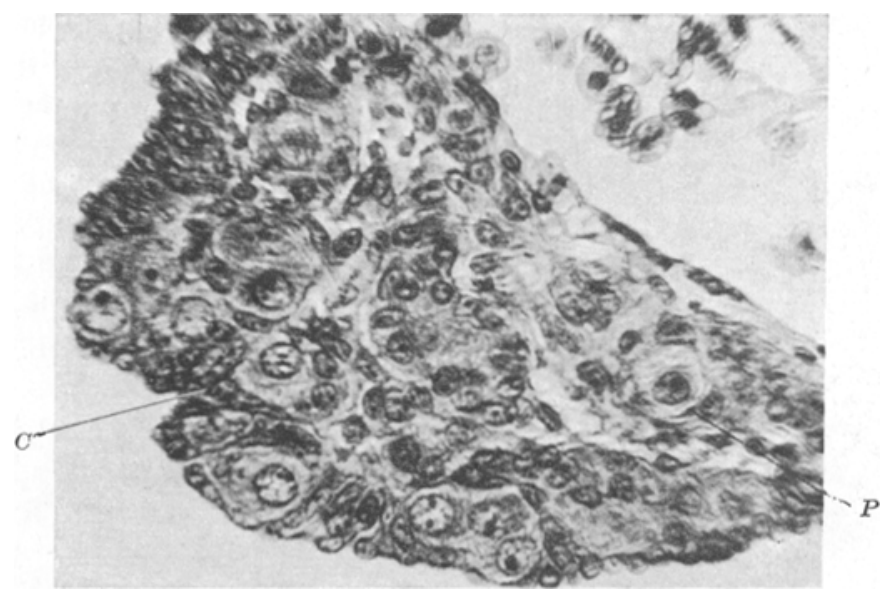

Fig. 5. Transection through an indifferent gonad of an embryo of $6.5 \mathrm{~mm}$. O. I. A sex cord is growing inward from the epithelium at $C$. The structure of other sex-cords and the development of the stroma of the gonad are illustrated. $P-$ primordial germ cell at the proximal end of a rete-cord. $(\times 435$.)

one or more primordial germ cells within (figs. 5 and 6 ). When such delimited groups are traced, they are usually found to be attached to the epithelium or to a sex-cord which has an epithelial connection. This is interpreted to mean that these groups of cells (now sex-cords) have also issued from the epithelium as groups and as outgrowths from the epithelium, or that some of the primordial germ cells which entered the germinal ridge before its growth have been surrounded by epithelial cells and have been incorporated eventually within or adjacent to another sex-cord. As a matter of fact, isolated primordial germ cells are found occasionally among the differentiated stromal cells. There are no indications of a migration of stromal elements into the gonadal region from the mesonephros. Such an entrance is effectually prevented by the large mesonephric blood vessels which lie between the gonads and the main bodies of the mesonephroi. Only the corpuscles of the mesonephroi are in close contact with the gonads, and the mesenchyme there is not 
only scattered but shows little or no activity. In the preceding stages it was observed that the epithelial cells not only left the epithelial layer proper singly, but also in groups with primordial germ cells. Correlating this with the later findings, it is interpreted that the single cells differentiate into stromal cells and separate the groups which become the sex-cords by retaining their epithelial attachments and establishing

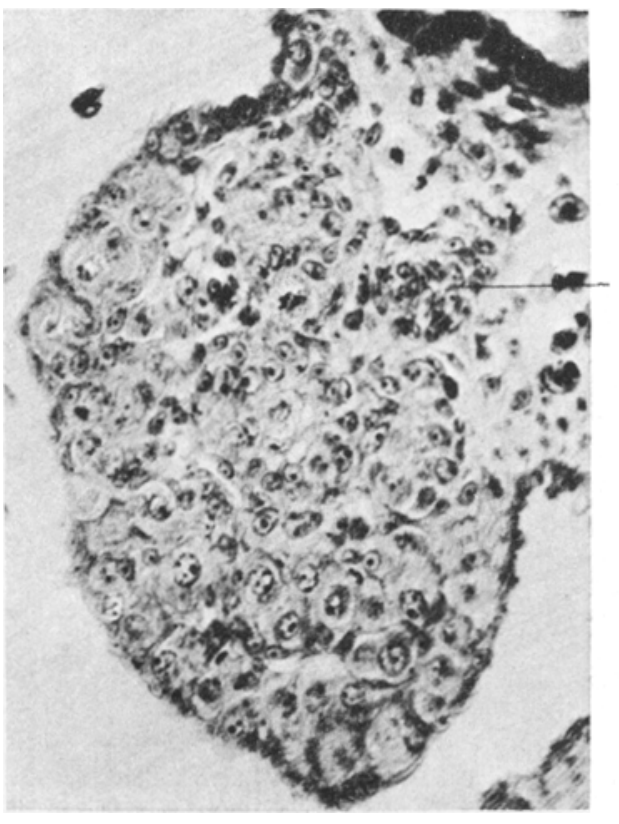

Fig. 6. Transection through an indifferent gonad of an embryo of $7.0 \mathrm{~mm}$. C. L., showing the further division of the primordial germ cells, the formation of the basement membranes of the sex-cords, and the struoture of the epithelium and the sex-cord. A rete-cord is seen at the base of the gonad. ( $\times 326$. further connections with other sex-cords and rete-cords with additional growth.

Not all of the primordial germ cells enter the germglands, for some of them are still to be found in the mesentery in the vicinity of the dorsal aorta and the mesenthyme above it, in the intestine, and in the adrenal glands. Those in the mesentery even divide and form

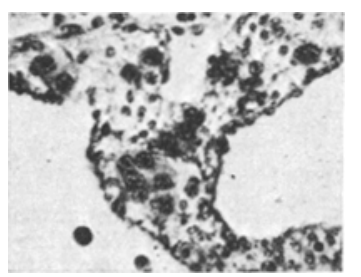

Fig. 7. Transection throught he mesentery of an embryo of $7.0 \mathrm{~mm}$. C. L., showing islets of primordial germ cells. $(\times 17.5$.

groups or islets of germ cells, which are closely invested with flattened mesenchymal cells (fig. 7). Many divisions of the primordial germ cells occur in the gonads where they appear in all stages of mitosis. Some of the germ cells even retain their yolk granules up to this period and such yolk-containing cells have been observed in the gonads as late as the $11.0 \mathrm{~mm}$. C.L. embryos. A few are in the process of degeneration, but these are rare. No transition stages from epithelial cells to germ cells have been observed up to this period.

The structure of the undifferentiated gonads of the turtle is comparable with that of the indifferent sex-glands of the bird and the mammal. The gonad is covered with an epithelial layer of two or three cells in thickness which invests one or several primordial germ cells. Beneath 
this cortical covering is the stromal tissue which separates several sexcords from each other and provides supporting membranes for the cords. Blood vessels are beginning to enter the stromal tissue. The sex-cords are without lumina and consist of a double layer of epithelial cells of no uniform arrangement (fig. 6). In the center of the cords are numerous primordial germ cells or their daughter cells. The sex-cords are irregularly arranged in some sections and apparently anastomose freely throughout the gland. In other sections, however, they extend directly inward from their attached loci in the epithelium to meet the rete-complex at the base of the gonad.

\section{B. The development of the cortex and medulla. - A period of bisexuality.}

In the typical indifferent gonads, the primordia of the cortex and the medulla, ovarian and testicular structures respectively, are organized

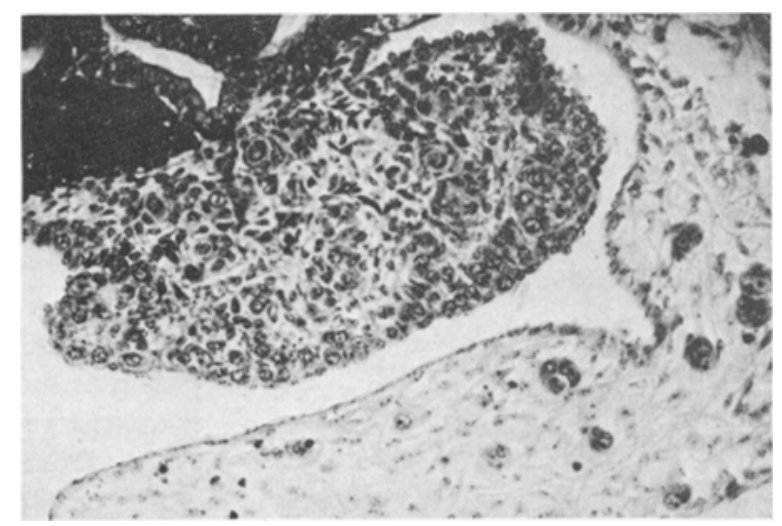

Fig. 8. Transection through a gonad of an embryo of $7.6 \mathrm{~mm}$. C. L., showing the beginning of mesogonium formation and the attachments of the sex-cords to the epithelium. $(x 168$.)

out of an epithelial blastema. The epithelial covering of the gonad is destined to become thicker and definitely an ovarian cortex consisting of two types of cells, epithelial and primordial germ cells or their descendants. The sex-cords, of the same constitution as the cortex, and the stroma and blood vessels make up the medulla of the germ-gland. This entire period (embryos of $7.5 \mathrm{~mm}$. C. L. to $14.0 \mathrm{~mm}$. C. L.) is one of growth and further organization of the elements present in the indifferent gonads. It is of especial interest that, in all cases, the gonads have both testicular and ovarian portions, which inserts a bisexual phase into the developmental period. One would naturally expect sex differentiation to occur immediately as it does in the birds and the mammals, but contrary to our expectations, the indifferent gonads remain indeterminate as to sex. The cortex and medulla grow and 
differentiate apparently quite independently and sex differentiation is incomplete.

Embryos of 7.5 to $10.0 \mathrm{~mm}$. C. L. In transverse section, the contour of the gonad is semi-circular or oval, while the base is flattened where the genital tissues meet the mesonephros (fig. 8). The attachment to the mesonephros is almost as wide as the gonad, but with further growth, it becomes thinner to form the supporting mesogonium (compare fig. 8 with the following figures). The formation of the mesogonium is not

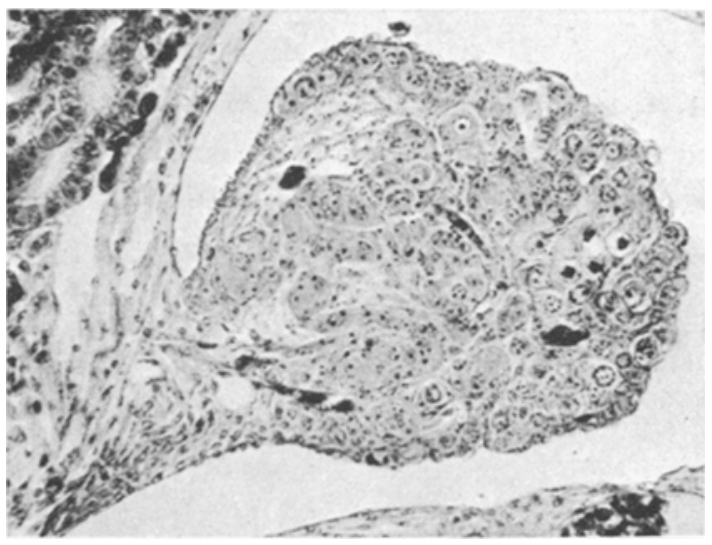

Fig. 9. Transection of a gonad of an embryo of $8.5 \mathrm{~mm}$. C. L., showing the development of the cortex, early appearance of synizesis in the germ cells (oöcytes), and the character of the sex-cords. $(\times 175$. due to an actual constriction of the peritoneum; it is dependent rather upon the progressive enlargement of the germ-gland in its more peripheral regions together with an elongation of the growing mesogonium.

The medulla of an early indeterminate gonad contains from three to four sex-cords which are separated from each other by a few stromal elements. The cords course more or less irregularly from their points of union with the epithelium to their basal attachments with the retecords or adjacent sex-cords. Occasional sections are found in which they extend directly inward from the germinal epithelium, but, as a rule, they anastomose more or less freely throughout the medullary area. Each sex-cord, if cut in longitudinal section, appears as a double row of columnar epithelial cells, among which are several primordial germ cells. The germ cells are usually located in the central part of the cord, which, if cut in cross-section, resembles a follicle with epithelial elements surrounding a much larger germ cell. A definite basement membrane distinctly marks off the stromal elements from the epithelial cells of the sex-cords. During this period, the width of the sex-cords is increased, and the cellular constituents undergo a rearrangement in such a way that the epithelial cells become oriented with their oval nuclei perpendicular to the basement membrane. In some of the cords, there is a tendency towards the formation of central cavities or lumina, but this is not general. The germ cells come to lie closer to the basement membrane, although they may remain approximately central in position (fig. 9). 
In earlier stages, the epithelium of the gonad consisted of a layer of two or three elongated cells among which were a few or several primordial germ cells. This forms the primordium of the cortex of the gonad; it extends around the periphery as a layer of uniform thickness which narrows down to a single layer of peritoneal cells as it nears the mesonephric wall (figs. 6 and 8). The surface epithelium, at first made up of columnar elements, comes to contain cells which are greatly flattened primarily because of the rapidly multiplying primordial germ cells. It is not smooth in appearance, for it is indented at the points

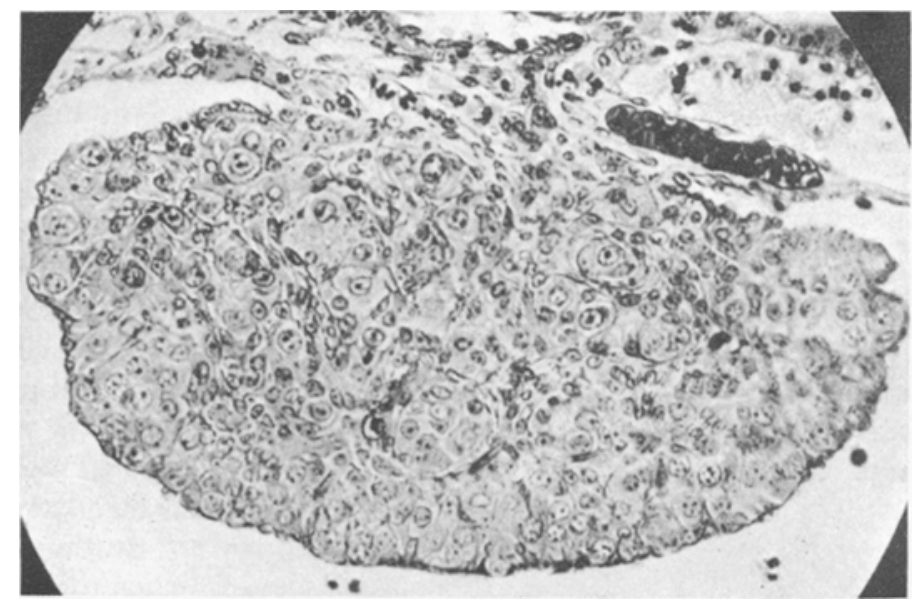

Fig. 10. Transection of a gonad of an embryo of $9.5 \mathrm{~mm}$. C. L. The basement membranes of the sex-cords and the lobulations of the cortex are clearly visible. Many germ cells are in stages preparatory to division or the entrance to synzesis. The typical bisexual character of the gonad is obvious. ( $x$ 248.)

where the sex-cords took their origin and to which they remain connected. The cells of the deeper part of the epithelium are usually flattened and elongated with their long axes perpendicular to the cells of the surface. This is due not only to the pressure exerted upon them by the dividing germ cells, but also to the fact that at the same time the epithelial cells are enlarging and differentiating to form epithelial elements of the sexcords. The growth of the cortex is dependent upon the differentiation of the deeper cells of the epithelial layer, multiplication of the epithelial elements, and especially divisions of the primordial germ cells.

Because of the numerous mitoses of the germ cells, the cortex soon becomes lobulated in appearance. The lobules consist of numerous germ cells with epithelial cells scattered between and among them and around the peripheries of the groups (fig. 10). The production of these lobules by the division of the germ cells appears to correspond to the formation of a secondary series of cords, or the cords of PFLÜGER, as described by 
SwIFT (1915) and GoLdSMITH (1928) in the formation of the ovary of the chick, and by others in the development of the mammalian ovary. In Sternotherus, however, there is, in no instance, any tendency for the

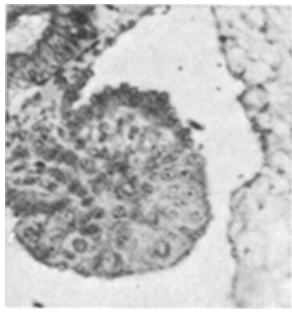

Fig. 11. A cross-section through the anterior end of a gonad of an embryo of $9.0 \mathrm{~mm}$. C. I., showing the typical ovarian character of the bisexual gonads in the anterior and posterior regions. $(\times 175$. stroma to separate the lobules from the covering epithelium. The absence of stromal tissue, which forms the tunica albuginea of the definitive ovary of birds and mammals and reduces the epithelial covering to a single layer of cells, is peculiar to the reptiles. The cortex of the chelonian ovary is the thick epithelial layer and its contained germ cells. The germ cells are not separated from the epithelium by the formation of definite cortical cords which are eventually cut off by an enveloping stroma. In this respect, the chelonian ovary resembles the ovary of the amphibians.

The anterior and posterior regions of the gonads appear as spadelike protrusions into the body cavity (fig. 11). As the sections are followed anteriorly or posteriorly, the sex-cords become less numerous and finally disappear. The cortex remains present in the most anterior and posterior regions where it surrounds a medullary area of stromal cells only. The sex-cords are confined to the more central region of

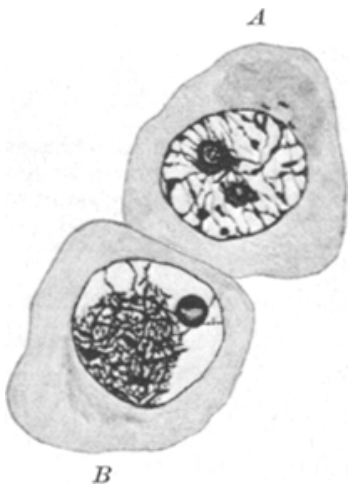

Fig. $12 A$ and $B$. A. A characteristic resting germ cell of the cortex of a gonad of an embryo of $9.0 \mathrm{~mm}$. C. L.

$B$. An oöcyte in synizesis. $(\times 1460$. the gonad. It is obvious that the extremities of the gonads are of a typical ovarian organization.

Many interesting changes appear in the germ cells during karyokinesis. The spherical or occasionally lobate nuclei of the germ cells differ in many respects from the ovoid nuclei of the epithelial and stromal cells (fig. 6). The nuclei of the epithelial cells are always smaller, oval in outline, and contain one or more nucleoli; the chromatin is evenly distributed throughout the nuclei in the form of a granular network. They take a uniform stain which is not as intense as the stain of the nuclei of the germ cells. The nuclei of many of the germ cells are characteristically in an early stage of mitosis or meiosis, in which the chrom-

atin is localized on a thread-like network in the form of granules of various sizes (fig. $12 \mathrm{~A}$ ). The nucleus is vesicular in appearance; the karyoplasm is clear. The chromatin nucleolus of earlier stages divides occasionally to form several smaller ones. This was described by ALLEN (1906) as occurring in the sex cells of Chrysemys embryos of about the 
same stage. The typical fine threads of the early prophase stages of mitosis have not been observed, and the definitive chromosomes of the mitotic figure are produced by a gradual thickening and enlargement of the chromatin granules which apparently form a center for chromosome formation and, therefore, might be considered as prochromosomes. A nucleus in a prophase stage is shown in fig. $13 \mathrm{~A}$. The chromatin of the germ cells is more basophilic in staining capacity than the chromatin of the other gonadal elements, as is typical of any cell in a mitotic stage. In the cortex, it is not unusual to find as many as six or eight division figures in any single cross-section. Often the germ cells of a cortical lobule are in the same stage of mitosis, and the lobules then resemble the cyst-like structures of the ovaries of the lower vertebrates. In the sex-cords, mitotic figures are found on the average in about every third or fourth section. The divisions of the germ cells of the sex-cords are less

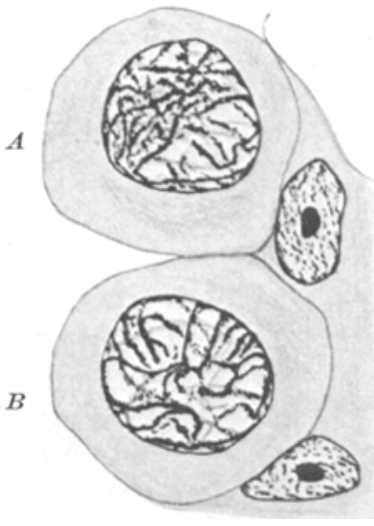

Fig. 13. A. A germ cell in an early prophase of mitosis, and comparable with one in a leptotene stage of meiosis. $B$. A germ cell entering synizesis. $(x$ 1460.) frequent but more consistent than those of the cortex, where they occur rapidly and soon come to an almost complete cessation.

The cortex of the gonads from $8.0 \mathrm{~mm}$. (C.L.) embryos is the scene of further nuclear changes which immediately suggest degeneration. This is not the case, however, for such germ cells are passing into normal maturation stages which follow periods of multiplication. Towards the end of the period of multiplication, the chromatin becomes more distinct and the granules larger. The granules vary in size as do the chromosomes of the reptiles. The larger ones as a rule are located peripherally close to the nuclear membrane, and

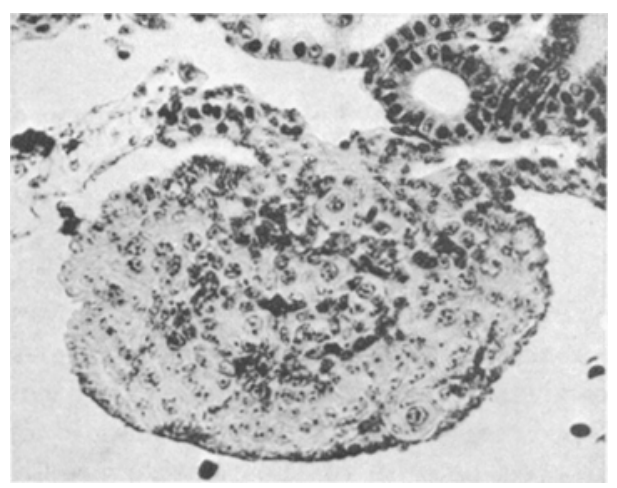

Fig. 14. A cross-section through the posterior third of a gonad of an embryo of $10.0 \mathrm{~mm}$. C. L., showing an expected male character with the absence of the cortex. It is probable that this is an abnormality in cortex development, since the gonad of the opposite side shows a far greater growth of the cortical area. $(x$ 212. $)$

the smaller ones are dispersed irregularly in the center of the nucleus. They are loosely connected by fine threads. This appearance suggests and 
apparently corresponds to the leptotene stage of VON WINIWARTER and SaINmont (1909). The masses of chromatin which resemble prochromosomes begin to clump together (fig. $13 \mathrm{~B}$ ) and pull away from the nuclear membrane, except along one side. They form a tangled mass of threads and granules, which soon coalesce into a dense mass of chromatin as shown in fig. $12 \mathrm{~B}$. The nuclear membrane remains distinct and the nucleoli are usually entangled in the chromatin mass which, as a rule, is on that side of the nucleus adjacent to the

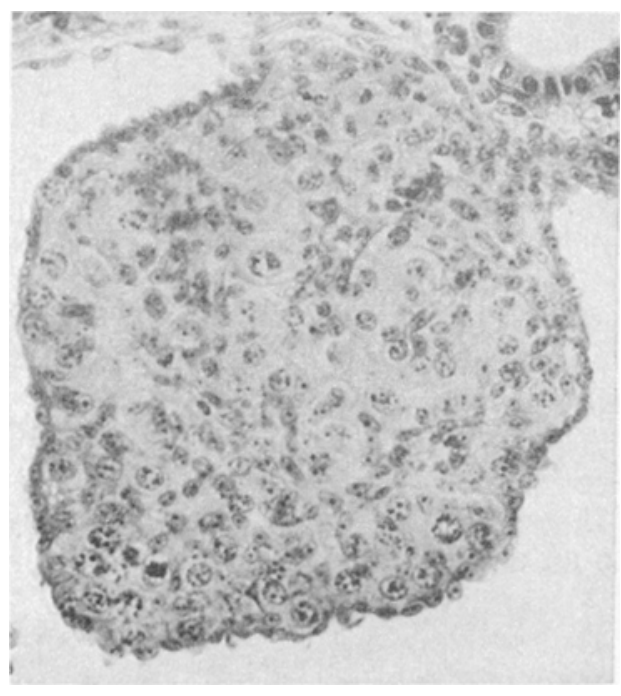

Fig. 15. Transection of a gonad of an embryo of $11.0 \mathrm{~mm}$. C. L., showing the presence of a cortex with oöcytes in synizesis, but with well-developed sex-cords. It is probably differentiating into a testis. $(x 292$. $)$ attraction sphere. Occasionally cells appear in which a large nucleolus lies to one side of the clumped chromatin in a clear vesicular space at the opposite pole of the nucleus. A few chromatin threads may radiate outward from the synizetic mass to the nuclear membrane at the opposite side. That these cells are passing into a normal contraction stage of maturation, i.e. synizesis, and furthermore that they are female auxocytes can not be questioned. The appearance of the heterotypic phases of maturation permits the germ cells to be definitely identified as oögonia and oöcytes in the cortex and as spermatogonia in the sex-cords.

Embryos of 10.0 to $14.0 \mathrm{~mm}$. C. L. The same general conditions as found in the previous stages prevail throughout this stage. It is not possible to determine whether the gonads are testes $\mathrm{O}_{\mathrm{i}}$ ovaries, for all of them exhibit a dual character with a medullary area of well developed sex-cords and an epithelial cortex. In some exceptional instances, because of the relative progress of the growth of the medulla and the cortex, it is possible to ascertain that the male characters are dominant over the female, or vice versa. In other cases, both medulla and cortex appear to be equally well developed.

A cross-section through the posterior third of a gonad of a $10.0 \mathrm{~mm}$. (C. L.) embryo shows it to be predominantly male in character (fig. 14). The gonad is rounded in shape and its epithelium has become reduced to a single layer of cells including several germ cells. However, the epithelium of the opposite gonad of this embryo still possesses a thickened 
cortical layer which is most prominent on the ventro-median border of the gland. The epithelium of the ventro-lateral surface is reduced to a simple layer of cuboidal cells, and the tunica albuginea lies directly beneath it. At various points, a well-defined cortex contains numerous germ cells, none of which are in synizesis as yet, although many are in mitosis. The cortex in this instance either has been reduced to a minimum or has not yet developed to its fullest extent. It is irregular in its appearance, suggesting that it develops particularly in places where the primordial germ cells had remained in the epithelium after the formation of the sex-cords. Both the anterior and posterior ends of the gonads of this embryo show the cortical area to the almost total exclusion of the sex-cords, as do the other embryos of this group.

The attachment of the sexcords to the epithelium makes it somewhat difficult to determine whether the cells are actually a part of the cortex or are simply aggregations of germ cells at the point of attachment. In many places where the cortex does appear, close examination shows that no attachment to a sex-cord can be found in the adjacent sections. In sections where the sex-cords do meet a pronounced thickening of the

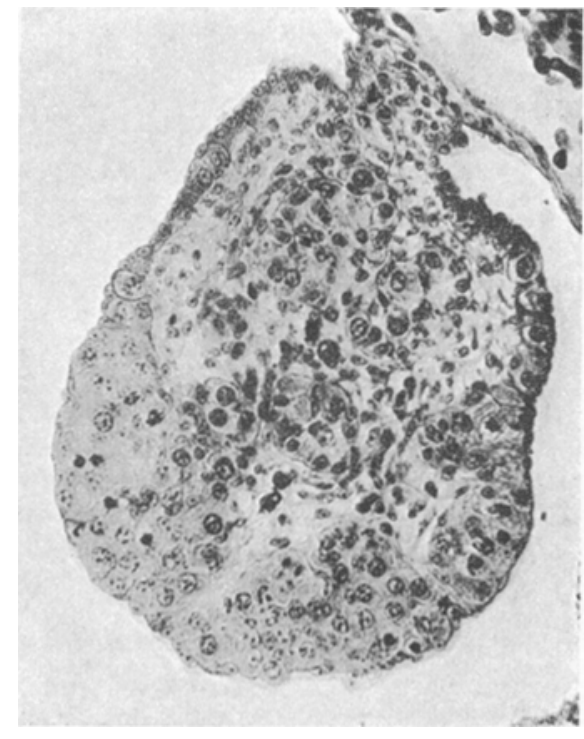

Fig. 16. A cross-section of a gonad of an embryo of $11.5 \mathrm{~mm}$. C. L. with well-developed cortex and narrow sex-cords. This type is interpreted as differentiating into an ovary. ( $\times 212$. epithelium, the thickened epithelial portion is preferably considered as a part of a sex-cord, which lies parallel with the surface layer. There is no tunica albuginea to separate the sex-cords from the cortex, and there is no intervening structure by which one can separate them. To determine between medulla and cortex, it is necessary to consider the extent of the stromal tissue of the medulla.

Another embryo of $11.0 \mathrm{~mm}$. C. L. is somewhat similar in its gonadal characters to the one just described. The gonads are larger and the sex-cords are better developed than in the preceding case (compare figs. 14 and 15). The cortex is relatively thin, but nevertheless welldefined, containing oögonia as well as oöcytes in synizesis. The germ cells of the sex-cords (spermatogonia) are in division and the germglands are predominantly testicular. There is every indication that this 
embryo was destined to become a male. It must be said that a testis ouring the early stages resembles an ovary in which the cortex is poorly developed.

Likewise, a developing ovary of this group appears to be a testis with a highly developed cortex. Such a gonad which the author interprets as an ovary is illustrated in fig. 16 . The cortex is very thick and extends completely around the gonad to the developing mesovarium. The stromal tissue is more abundant. The sex-cords are still attached to the cortex

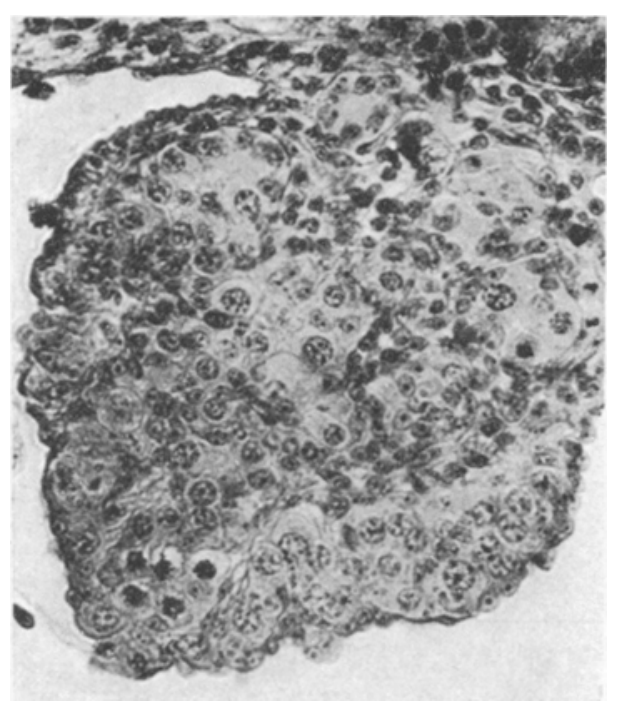

Fig. 17. A transection of a bisexual gonad of an embryo of $11.5 \mathrm{~mm}$. C. L. This is the typical condition found in embryos of 10.0 to $14.0 \mathrm{~mm}$. C. L. ( $\times 292$. and are somewhat thinner and less developed than those illustrated in figs. 14 and 15. Numerous primary oöcytes in synizesis and also dividing oögonia are present. The germ cells of the sex-cords are also in mitosis, indicating the male potentiality of the gonad.

The attachments of the sex-cords to the epithelial cortex persist until an ovary or a testis is definitely formed. Their relations will be more fully considered below. It has been impossible to distinguish the sex of the gonad on the basis of the width of the sex-cords or upon size differences as ALLeN (1906) was able to do in embryos of Chrysemys. In em. bryos of $11.5 \mathrm{~mm}$. C. L., he found a differential distribution of the germ cells, which he described as occurring more frequently in the epithelium of the ovary than in the medullary cords, but as being more numerous in the sex-cords of the testis than in the epithelium. There seem to be no outstanding differences in germ cell distribution in the gonads described above. The relative amounts of medulla and cortex are the only differences which exist. It is difficult to find any characters which will allow one to say with certainty that one gonad will become a testis and another an ovary, other than the general appearance of the sections. This is due to the great variability which appears in the gonads of these stages. For example, fig. 17 is an illustration of a gonad which is typically hermaphroditic and cannot be identified as one of any particular sex. It must be classed as a bisexual germ gland. The medulla and cortex 
are equally well developed in size and differentiated in structure. Such specimens as this one are by far the most frequently observed in my collection of embryos, and must be considered as typical for this stage of development.

There is apparently some tendency for sex differentiation to begin during the embryonic stages from 10.0 to $14.0 \mathrm{~mm}$. C. L. Complete sex differentiation is not accomplished until the $14.0 \mathrm{~mm}$. C. L. stage is attained, and accurate diagnosis of the sex of a gonad or embryo is not possible until that time. One can ascertain, however, in some cases, the direction in which the differentiation is proceeding with a reasonable degree of certainty.

\section{Sex differentiation.}

\section{Macroscopic observations.}

Throughout the entire period of sex differentiation which includes the developmental period from the time of the $14.0 \mathrm{~mm}$. C. L. embryos to hatching, differences in the gross anatomical structure of the male and female urogenital systems are relatively few and are only distinguishable after a close examination and comparison of numerous specimens. Even then one remains somewhat in doubt until the observations have been closely checked by a microscopic examination of the germ glands themselves. The variability in the size of the sex organs parallels the variability in the general embryonic growth rate; this obviously makes an accurate macroscopic diagnosis of the sex of any individual difficult. For convenience of comparison, the embryos examined during this period of development have been grouped into five representative stages based on the length of the carapace and their approximate ages from the time of egg-laying (see taible 1).

The gross structure of the adult male and female urogenital systems in turtles is relatively simple, although the presence of the pro-, meso-, and metanephroi, and phallus makes them more complex than in the lower vertebrates. The adult systems may be compared with the urogenital system of the indifferent stages of development as follows (degenerate and vestigial structures are starred):

\begin{tabular}{|c|c|c|}
\hline Indifferent stages & Adult males & Adult females \\
\hline $\begin{array}{l}\text { 1. Indifferent gonads } \\
\text { 2. Rete-cords } \\
\text { 3. Mesonephros } \\
\text { 4. Metanephros } \\
\text { 5. Metanephric duct } \\
\text { 6. Woufrian duct } \\
\text { 7. MüLLERian duct } \\
\text { 8. Phallus } \\
\text { 9. Hind-gut } \\
\text { 10. Allantois }\end{array}$ & $\begin{array}{l}\text { 1. Testes } \\
\text { 2. Rete-testis } \\
\text { 3. Vasa efferentia-Epidi- } \\
\text { dymis } \\
\text { 4. Metanephros. } \\
\text { 5. Ureter } \\
\text { 6. Vas deferens } \\
\text { 7. Oviduct* } \\
\text { 8. Penis } \\
\text { 9. Cloaca } \\
\text { 10. Bladder }\end{array}$ & $\begin{array}{l}\text { 1. Ovaries } \\
\text { 2. Rete-ovarium* } \\
\text { 3. Epoöphoron* } \\
\text { 4. Metanephros } \\
\text { 5. Ureter } \\
\text { 6. Epoöphoron* } \\
\text { 7. Oviduct } \\
\text { 8. Clitoris* } \\
\text { 9. Cloaca } \\
\text { 10. Bladder }\end{array}$ \\
\hline
\end{tabular}


The close of the indifferent period, represented in embryos of $7.0 \mathrm{~mm}$. C. L. and of about 24 days of incubation, finds the primordia of all of the above-mentioned organs present in every embryo. The observations recorded here are concerned only with the reproductive organs. During the egg stage, there are only three extragonadal reproductive organs present. These are: first, the phallus; second, the MüLLERian ducts; and third, the mesonephros, which becomes the epididymis of the male reproductive system and the vestigial epoöphoron of the female.

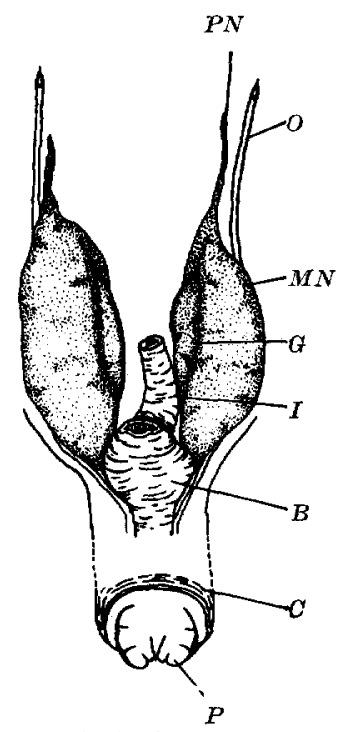

Fig. 18. A ventral view of the urogenital system of a typical embryo of the 7.5 to $10.0 \mathrm{~mm}$. C. L. stage. $P N$ Pronephros. $M N$ Mesonephros, $G$ Gonad. $I$ Intestine. $B$ Urinary bladder. $C$ Cloaca, $P$ Phallus. $D$ oviduet. $(\times 10$. $)$

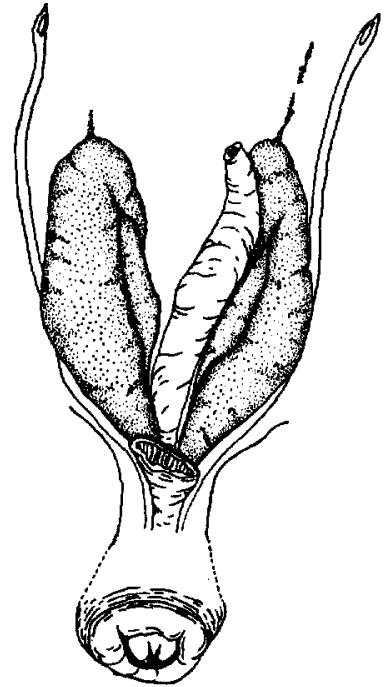

Fig. 19. Ventral view of the urogenital system of a typical embryo of the 10.0 to $14.0 \mathrm{~mm}$. C. L. stage. $(\times 10$.

The phallus begins its development at the time of the appearance of the carapace, and appears first as a prominent projection of the ventral wall of the hind-gut. It increases in size during the indifferent period, and at the end appears as a bilobed structure which borders the cloacal opening, projecting outward below and overlapping it (fig. 18). A dorso-median gropve separating the two lateral lobes is destined to become the urogenital groove which normally remains open throughout the life of the turtle. Further details on the early development of the cloaca are related by HzLnmutr (1902) on Emys lutaria, and by SCHMIDTGEN (1907).

The origin of the MüLLERian ducts occurs simultaneously with the appearance of the sex-cords of the gonads (embryos of 5.0 to $6.0 \mathrm{~mm}$. C. L.). The primordia of the MüLLERian ducts are laid down on both 
sides of the embryo in the germinal ridge stage. Each duct is represented by a strip of thickened peritoneum (tubal ridge) on the dorso-lateral

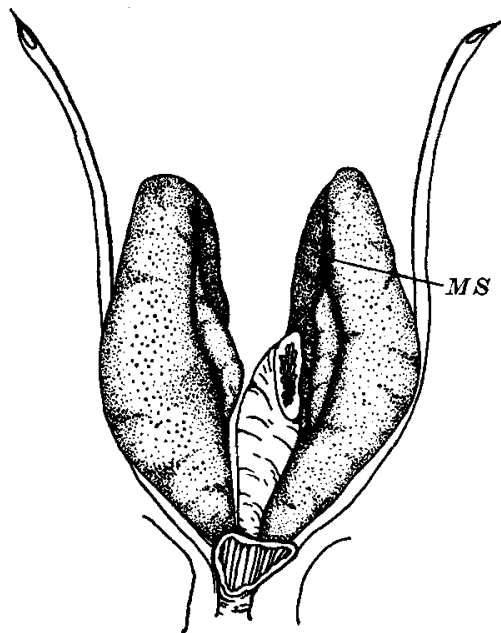

Fig. 20.Ventral view of the urogenital system of a female embryo of the 14.0 to $17.0 \mathrm{~mm}$.

C. L. stage. $M S$ Metanephros. $(\times 10$. wall of each mesonephros, immediately laterad of the WoLFFian duct

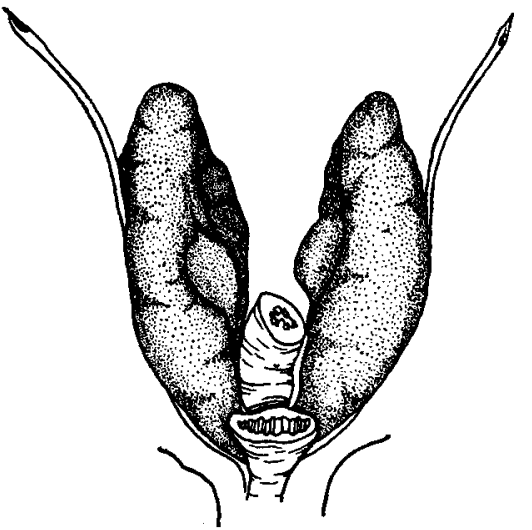

Fig. 21. Ventral view of the urogenital system of a male embryo of the 14.0 to $17.0 \mathrm{~mm}$. C. L. stage. $(\times 10)$.

(fig. 1). The duct makes its first appearance as a groove-like depression in the anterior end of the tubal ridge in the vicinity of the pronephros.

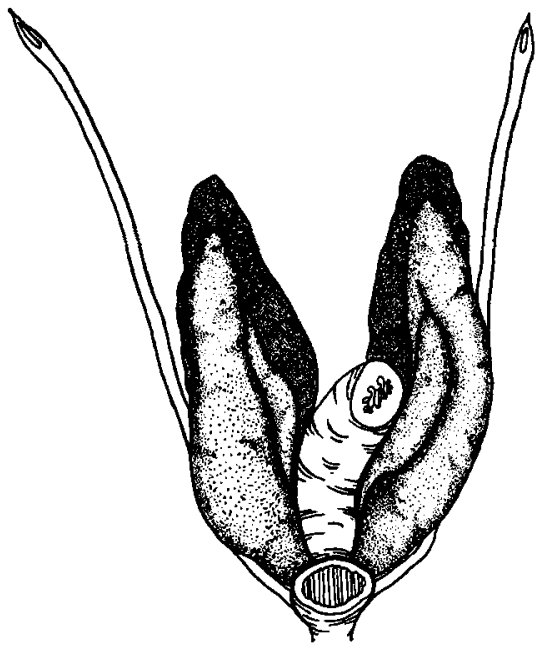

Fig. 22. Ventral view of the urogenital aystem of a female embryo of the 17.0 to $20.0 \mathrm{~mm}$. C. L. stage. ( $x$ 10.)

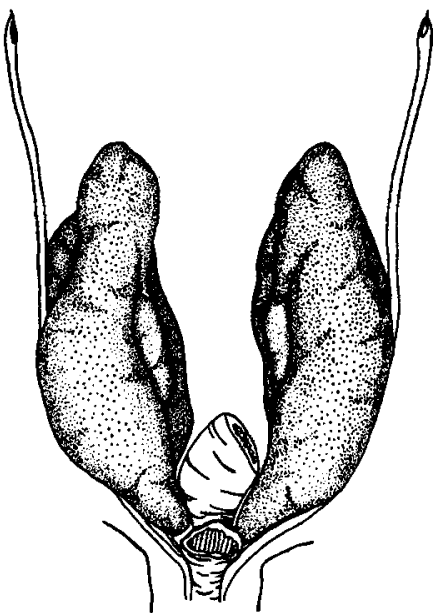

Fig. 23. Ventral view of the urogenital system of a male embryo of the same stage as Fig. 22. $(\times 10$.

A hollow tube, remaining open at the anterior end as the coelomic opening of the oviduct, separates off from the ridge and grows caudally. 
At the end of the indifferent period, they extend posteriorly as far back as the gonads. In the males, they never open directly into the cloaca. In the females, the communication with the cloaca is established after hatching. Development of the MüLLERian ducts occurs in a manner similar to that in the chick (LILLIE, 1919), and in Lacerta agilis (BRAUN, 1877).

Since during the indifferent period no sex differences exist in any embryonic organ or part, and also since this similarity persists for some

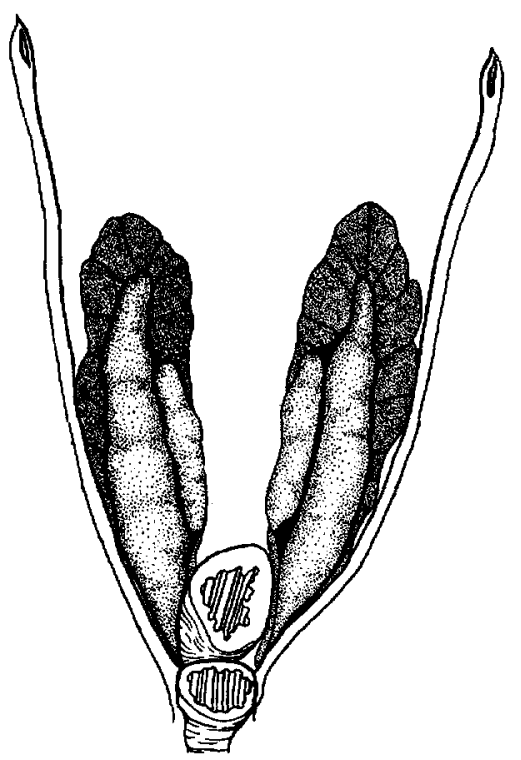

Fig. 24. Ventral view of the female urogenital system at the time of hatohing. $(x 10$. time into the period of sex-differentiation, our observations begin with

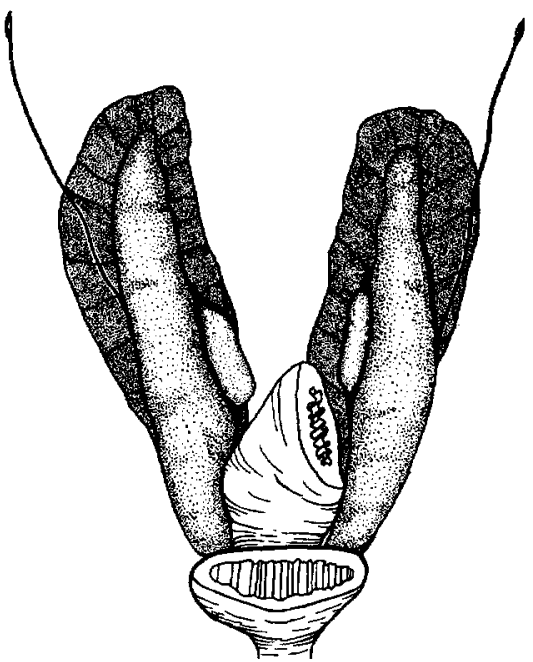

Fig. 25. Ventral view of the male urogenital system at the time of hatching. $(\times 10$.)

the urogenital systems of embryos of 8.0 to $10.0 \mathrm{~mm}$. C. L. (fig. 18). The gonads are smooth slender spindle-shaped bodies on the ventromedian surfaces of the mesonephroi. They are of such a translucent nature that, before observations can be made, it is necessary to subject them to fixation. They are about $1.2 \mathrm{~mm}$. in length and $0.25 \mathrm{~mm}$. in width at the widest point. No detectable differences exist between the gonads of the two sides. The mesonephroi are of a similar shape and are about $2.75 \mathrm{~mm}$. in total length and $0.9 \mathrm{~mm}$. in width at their largest diameters. The pronephros at the anterior end of each mesonephros appears as a slender mass of tubules which tapers anteriorly and disappears. Along the dorso-lateral wall of each mesonephros is an oviduct which extends posteriorly and soon disappears behind the lateral bulge of the mesonephros. At the posterior end of the WoLfFian body, it appears again and extends to the cloaca where it ends blindly at the cloacal wall. 
At the anterior end of each oviduct is an ostium tubae abdominale which opens to the coelom. The bladder and large intestine both lie in a caudal position between the mesonephroi. The metanephroi are hidden from view behind the mesonephroi. The phallus projects outward from

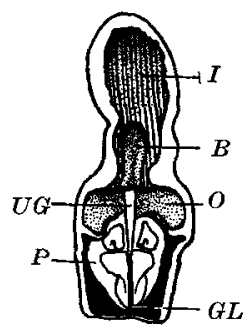

Fig. 26. A dorsal view of the interior of the female cloaca at the time of hatching. I In. testine. $B$ Opening of bladder, $O$ oviduet. $U G$ Urogenital groove. $P$ Phallus, $G L$ Glans penis. $(\times 10$.)

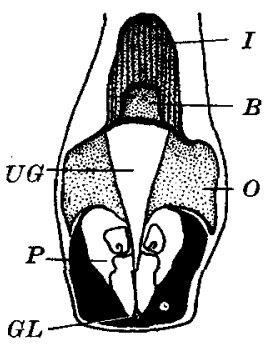

Fig. 27. Dorsal view of the cloacal interior of a male at hatching. Abbreviations as in Fig. 26. $(\times 10$. $)$

its ventral attachment below the cloacal opening, and it is now a many lobed organ which is being slowly surrounded by the walls of the cloaca.
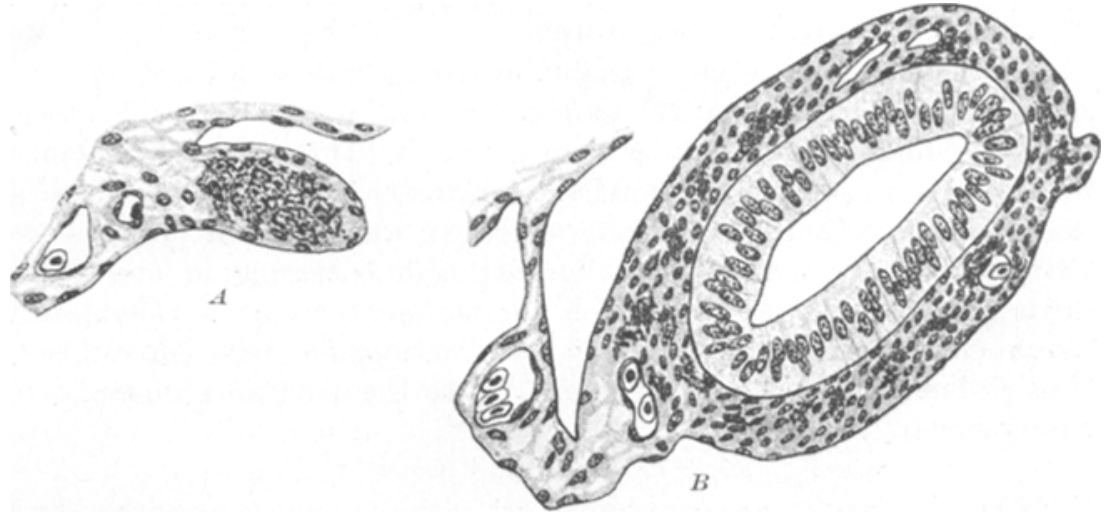

Fig. 28. A. Transection through the oviduet of a male at hatching. $B$. Transection of the oviduct of a female at hatching. $(x 165$.

The glans penis is differentiated and is a triangular pointed lobe on the posterior median ventral end of the phallus.

In embryos of 11.0 to $I 4.0 \mathrm{~mm}$. C. L., the only differences noticeable are the result of slight increases in size (Compare figs. 18 and 19). A uniform increase occurs as recorded in table II. The pronephros is reduced to a few vestigial tubules and the phallus is entirely withdrawn into the cloaca.

The gross differences between the male and female urogenital systems are primarily differences in the size and form of the gonads, the 
mesonephroi, the oviducts, and the phallus. These differences do not appear, or are not detectable, until after the stage of $14.0 \mathrm{~mm}$. C. L. and in embryos of about 40 days incubation. The changes occurring in the entire period of sex differentiation as measured with the binocular dissection microscope are given in Table II. The gonads of the male are reduced in size, becoming shorter and more rounded in form as the cortex and ovarian portions disappear. They are attached to the mesonephric wall by a mesorchium which is broad and elongated cephalocaudally. The gonads of the female remain of the same general form and size as in the earlier stages, but increase in length. The oviducts of the male begin their regression by a cessation of growth in the $14.0 \mathrm{~mm}$. stages, but a decrease in size is not discerned until the time of hatching, when in some embryos the oviducts may be reduced to a mere line of pigmentation (figs. 25 and $28 \mathrm{~A}$ ). In others, however, they may persist for some time; vestigial oviducts have been found in young sexually mature males. In the females, the development and growth of the oviducts progresses regularly. At the time of hatching, differences in the mesonephroi of the males and females are negligible, and they remain functional until some time after hatching. The progressive alterations in these stages are shown in figs. 20, 22, 24 and figs. 21, 23,25 for males and females respectively.

The phallus is extremely variable in size in both males and females. As shown in figs. 26 and 27 , they are perfect replicas of each other, but the clitoris is much smaller than the penis. The extreme variability in this organ makes it an unreliable character upon which to base a diagnosis of the sex of an embryo. FELIX and BüHLER (1906) state that, in Lacerta and Anguis, ,Vor der Differenzierung in der Keimdrüse selbst kommt es gewöhnlich zur Differenzierung des Geschlechts durch eine stärkere Entwicklung der Penispapille beim Männchen“". This statement does not seem applicable to the conditions observed in Sternotherus.

Table II. Average measurements of gonads, mesonephroi, and oviducts of $20 \mathrm{embryos}$ of each of the embryonic stages represented.

\begin{tabular}{|c|c|c|c|c|c|c|c|c|c|c|}
\hline \multirow{3}{*}{$\begin{array}{l}\text { Stage } \\
\text { C. L. } \\
\text { mm. }\end{array}$} & \multicolumn{4}{|c|}{ Gonads } & \multicolumn{4}{|c|}{ Mesonephros } & \multicolumn{2}{|c|}{ Oviducts } \\
\hline & \multicolumn{2}{|c|}{$\begin{array}{c}\text { Length } \\
\text { mm. }\end{array}$} & \multicolumn{2}{|c|}{$\begin{array}{c}\text { Width } \\
\text { mm. }\end{array}$} & \multicolumn{2}{|c|}{$\begin{array}{c}\text { Length } \\
\text { mm. }\end{array}$} & \multicolumn{2}{|c|}{$\begin{array}{l}\text { Width } \\
\text { mm. }\end{array}$} & $\begin{array}{l}\text { width } \\
\text { mm. }\end{array}$ & $\begin{array}{c}\text { Width } \\
\text { mm. }\end{array}$ \\
\hline & $\mathbf{F}$ & $\mathrm{M}$ & $\mathrm{F}$ & M & $\mathbf{F}$ & M & $\mathbf{F}$ & $\mathbf{M}$ & $F$ & $\mathbf{M}$ \\
\hline $9-10$ & 1.2 & 1.2 & 0.25 & 0.25 & 2.75 & 2.75 & 0.9 & 0.9 & 0.05 & 0.05 \\
\hline $11-14$ & 1.6 & 1.6 & 0.3 & 0.3 & 3.5 & 3.5 & 1.0 & 1.0 & 0.1 & 0.1 \\
\hline $15-17$ & 1.75 & 1.25 & 0.3 & 0.3 & 3.9 & 3.9 & 1.2 & 1.2 & 0.14 & 0.1 \\
\hline $18-21$ & 1.85 & 1.4 & 0.35 & 0.35 & 3.9 & 3.9 & 0.9 & 1.0 & 0.12 & 0.1 \\
\hline Hatching & 1.75 & 1.05 & 0.35 & 0.35 & 3.9 & 4.35 & 0.75 & 0.8 & 0.15 & 0.05 \\
\hline
\end{tabular}


System in the Musk turtle, Sternotherus odoratus (Latreille). II.

Table III. Tabulation and classification of the sex of several stages before and during sexdifferentiation as determined by macroscopic examination.

\begin{tabular}{|c|c|c|c|c|}
\hline $\begin{array}{l}\text { Stage } \\
\text { C.L. } \\
\text { mm. }\end{array}$ & No. Embryos & Indeterminate & Male & Female \\
\hline $\begin{array}{r}9-10 \\
11-14 \\
15-17\end{array}$ & $\begin{array}{l}20 \\
20 \\
19\end{array}$ & $\begin{array}{l}20 \\
20 \\
-\end{array}$ & $\overline{-}$ & $\overline{15}\left(12\right.$ $\left.; 3 \delta^{\top}\right)$ \\
\hline $18-21$ & 20 & - & 3 & $17\left(12 q ; 5 \sigma^{71}\right)$ \\
\hline Hatching & 31 & - & 13 & $18(18 \% ; 0$ 万) \\
\hline Totals & 110 & 40 & 20 & 50 \\
\hline
\end{tabular}

The results given in table III indicate very definitely the tendencies of the male embryos towards femaleness. Microscopic examination showed that a number of the macroscopically determined females were intersexes which were definitely becoming males. The number of intersexes for each of the above groups of females, respectively, were 3,5 , and 0 . It is evident from the above observations that the urogenital systems of the indeterminate stages are predominantly female in appearance, and that during the succeeding stages the male system is differentiated from an essentially female type. Also, from the numerical evidence, the proportionate number of recognizable males increases during the later stages.

2. Microscopic observations.

a) The development of the ovary. The definitive ovary is first recognized in embryos of $14.0 \mathrm{~mm}$. C. I. The main differentiating characteristic is in the relation of the cortex

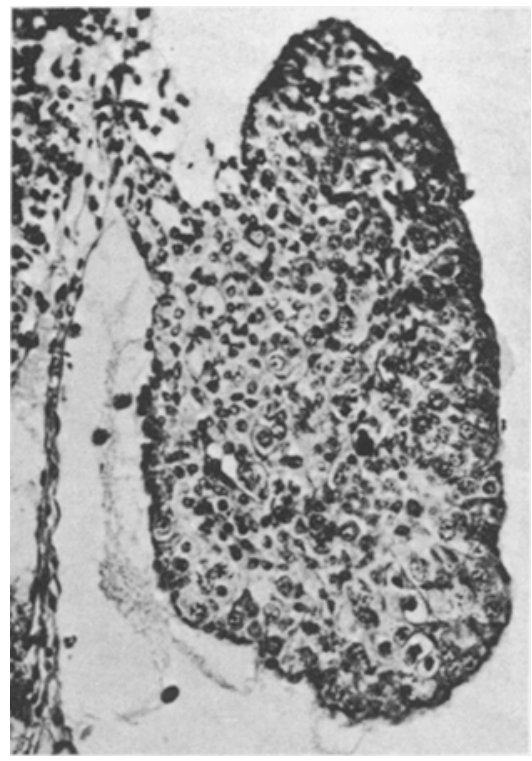

Fig. 29. Transection of an ovary of an embryo of $14.0 \mathrm{~mm}$. C. I. The cortex is well-defined, and the sex-cords are reduced and no longer attached to the cortical epithelium. Numerous germ cells are present in the medullary area. $(\times 212$. to the medullary cords, which have broken away from their attachments to the cortical area. Stromal elements definitely separate them and form a definite layer subjacent to the cortex. The medullary cords are reduced in size, and are beginning to degenerate with the formation of irregular cavities. Flattened stromal 
cells mark the position of the basement membranes of the cords and the cavity resembles to some extent that of a lymph sinus. In other sections, the cords are compressed into a thin two-celled cord and the

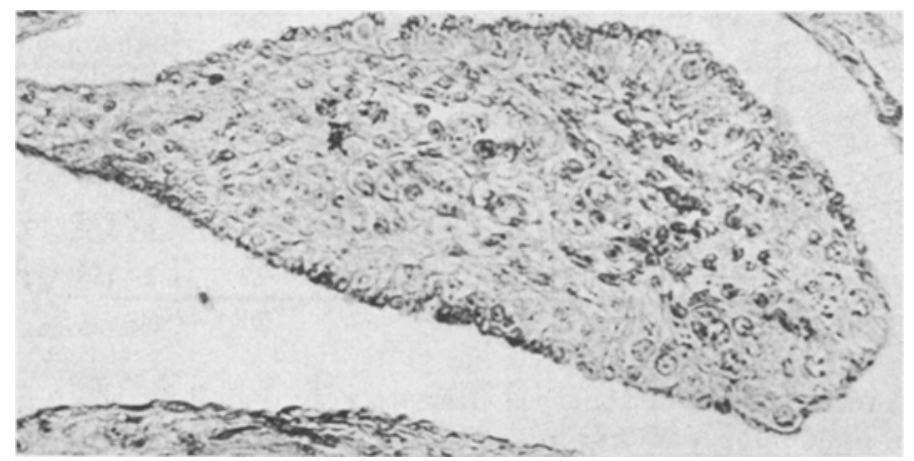

Fig. 30 . A cross-section of an ovary of an embryo of $14.0 \mathrm{~mm}$. C. L. In this specimen, the cortex is poorly developed and contains only a few oögonia. No new germ cells are being produced from epithelial cells, and the sex-cords of the medulla are degenerating. $(\times 292$.)

basement membrane is less definite (fig. 29). Germ cells are lying dormantly in the cords or within the cavities of the cord. The cortex shows little if any change from its

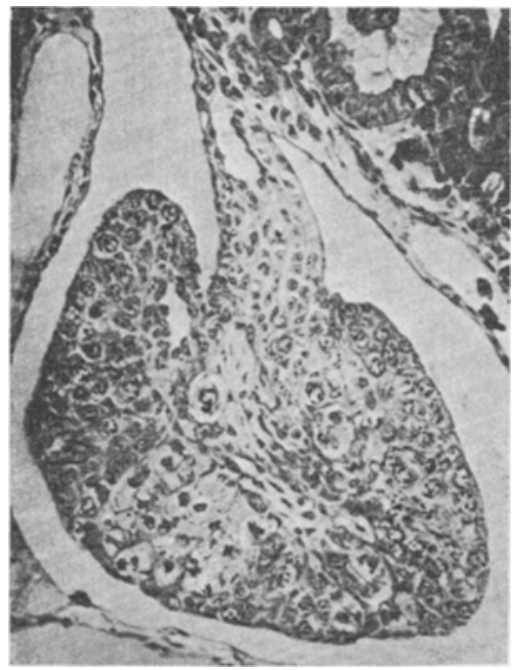

Fig. 31. Transverse section of an ovary of an embryo of $16.6 \mathrm{~mm}$. C. L. $(\times 168$. earlier appearance. Many oöcytes in synizesis are scattered among normal oögonia and the usual epithelial cells. It is more definitely outlined by the stromal tissues which are flattened against it.

The cortex of another ovary is most interesting because of a marked. deficiency in the number of germ cells. It is probable that the low number can be attributed to an original small number of primordial germ cells although a degeneration of some oöcytes may have already occurred. The absence of the germ cells offers an opportunity to examine the epithelial cells of the cortex more closely. The cells of the surface epithelium are closely packed together with their oval nuclei in a perpendicular relation to the surface. Beneath them is a syncytium of epithelial cells which is set off from the underlying stroma by a distinct membrana propria (fig. 30). The nuclei of the syneytium are in various 
positions and locations, some close to the surface, some central, and others close to the membrana propria. Some of the nuclei appear small and spherical but these present an end view. In such instances they are surrounded by a small clear area of cytoplasm and might easily be mistaken for epithelial elements which are metamorphosing into oögonia. However, the absence of the attraction sphere and the character of the nuclei do not permit such an interpretation.

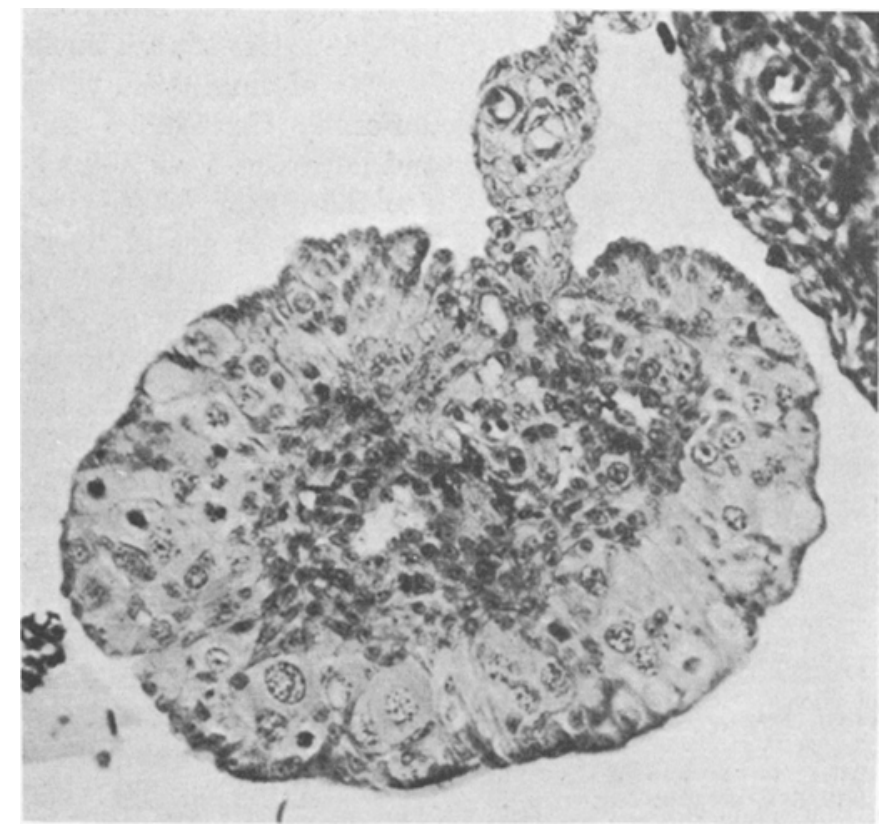

Fig. 32. Transverse section of an ovary of an embryo of $22.0 \mathrm{~mm}$. C. L., showing the beginning of the growth stages of the oöcytes. Germ cells are still present in the medulla as are some vestiges of sex-cords. $(x 274$.

In the ovary of a $16.6 \mathrm{~mm}$. C. L. embryo, many oögonia and oöcytes are present in the cortex, and nearly all of them are in synizesis with the exception of those in that part of the cortex immediately adjacent and lateral to the mesovarium (fig. 31). Undoubtedly many of these oöcytes in synizesis degenerate, for not all of them could possibly enter the growth period because of the smallness of the somatic ovary. Degeneration of these oöcytes is also illustrated, but will be described more fully later in connection with the degeneration of the cortex in testis development. The medulla of the ovary is almost completely reduced to stroma, blood vessels, and nerves, but occasional germ cells surrounded by a few epithelial cells represent the original sex-cords. 
No important changes occur between this stage and that of the 18.0 to $20.0 \mathrm{~mm}$. C. L. embryos. At this time, about ten days before hatching, the oöcytes which remain in the ovary begin their growth (fig. 32). Numerous germ cells in the medulla are in synapsis and others are degenerating.

Growth of the oöcyte begins during the synizesis stage, but soon afterwards the chromatin begins to spin out from its clumped or mas-

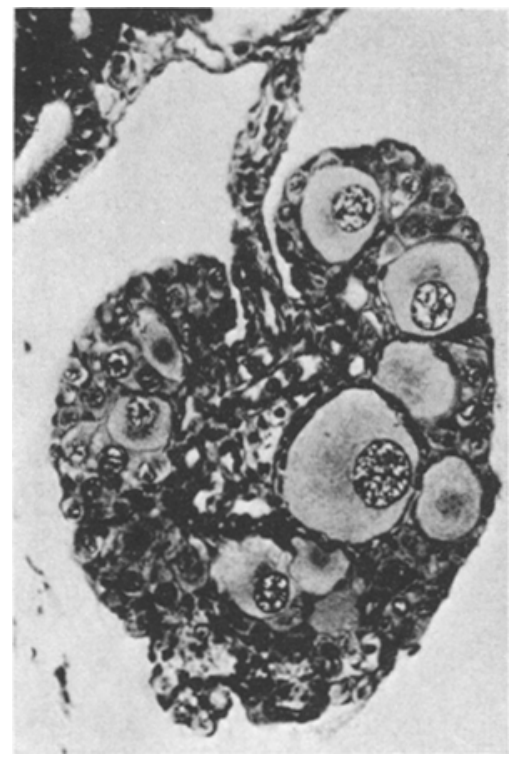

Fig. 33. Transection of an ovary taken at time of hatching, showing oöcytes in growth stages and follicle formation. Note the crescentic nuclei of the peripharal oögonia. $(\times 176$. sed condition and enters a pachytene stage of maturation. The pachytene threads are thick granular strands of chromatin, which extend uniformly throughout the nucleus and surround a nucleolus of smaller size than that of the resting cell. This stage is not of long duration but is correlated with the initiation of growth. At the same time, epithelial cells aggregate about the oöcyte to form a follicle, and the follicle sinks inward towards the medulla. A growing oöcyte with its follicle of epithelial cells is shown in fig. 33. The nucleus is larger and contains numerous nucleoli of varying sizes, while the chromatin is irregularly distributed in fine granules and strands. It returns to a resting condition without continuing its prereduction phases. The changes here (fig. 34) are similar apparently to those in the early growth of the oöcytes of the chick, as described by GoLDSMITH (1928). I do not find, however, that synizesis occurs previous to the usual leptotene stage as described by GoLDSMITH, nor that during synizesis the nuclear membrane disappears.

A cross-section through the ovary of a young turtle just after hatching shows no further changes in cortex and medulla (fig. 33). The oögonia and oöcytes are prominent in both regions. As the oöcytes and their follicles increase in size, they progress towards the center of the gonad where they become surrounded by stromal cells and blood vessels. The oögonia at the periphery of the cortex among and immediately beneath the cells of the surface epithelium form reserve or residual oögonia. The nuclei of these cells are crescentic in shape and the hollow of the crescent is occupied by the attraction sphere. AluEN (1906) also observed 
this differentiation in the germ cells of this region in both testis and ovary but offered no explanation of its meaning. Examinations of the adult testis and ovary have shown that many of the resting germ cells are in this condition, and it is probable that these represent reserve oögonia (spermatogonia in the testis) which give rise to new germ cells as occasion demands.

In summary, the action of two concurrent processes results in the production of the definitive ovary. The medullary cords lose their resemblance to the sex-cords of the testis, their attachments to the cortex, and begin to undergo re. gression. The cortex, on the other hand, persists and begins progressive alterations which manifest themselves in the formation of the ovarian follicles and in the growth of the germ cells.

b) The development of the testis. In the formation of the testis, two concomitant processes, the opposite of those in ovarian development, are involved, namely: (1) the continued autonomous growth of the sex-cords, and additions to them from the cortex by way of their attachments; and (2) the reduction and almost complete disappearance of the cortex. Variations in the

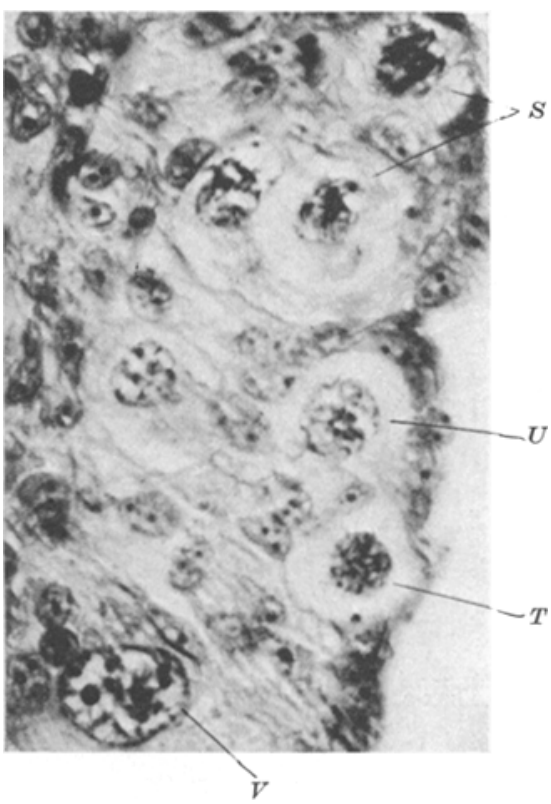

Fig. 34. An enlarged portion of the cortex of an ovary of the same stage as Fig.32, showing stages in the emergence of the oobcytes from synizesis and the entrance of the growth period. $S$ Synizesis. $T$ Emergence. $U$ pachytene threads. $V$ Nucleus of growing oöcyte. $(\times 968$. sizes of the gonads and the relative amounts of medulla and cortex are too great to allow a description of these changes in accordance with the size and age of the embryo. Accordingly a series of embryos has been selected to illustrate the successive gonadal alterations which occur from the $14.0 \mathrm{~mm}$. C. L. embryo up to the time of hatching $(20.0$ to $25.0 \mathrm{~mm}$. C. L.), when, as a rule, the cortex has diminished to an almost negligible part of the testis (see figs. 35, 36, 37, 38, and 39).

The sex-cords increase in number and width (figs. 35 and 36). No lvmen is formed until well after hatching, except in a few unusual cases when signs of vacuolization and disintegration of the cytoplasm appear. Spermatogonia are scattered more or less uniformly throughout the cords, which fill the medulla and anastomose with each other in every conceivable manner. Small amounts of stromal tissue, blood vessels 
and nerves constitute the intertubular structure. The presence of interstitial cells amidst the stromal elements has not been observed;

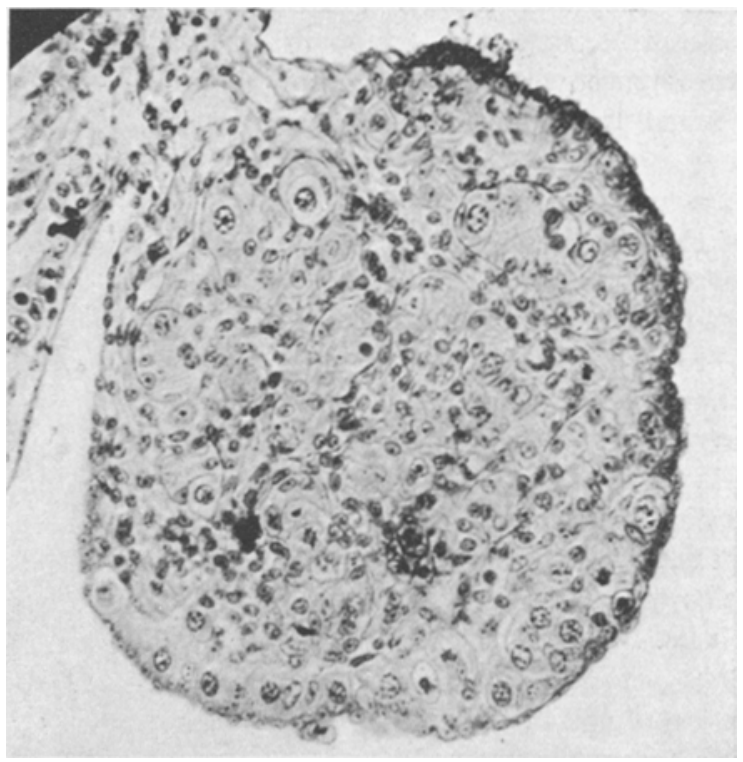

Fig. 35. Transection of a gonad of an embryo of $12.0 \mathrm{~mm}$. C. L. The cortex is reduced and the sex-cords are well-developed, representing an early stage in testis formation. ( $\times 236$.)

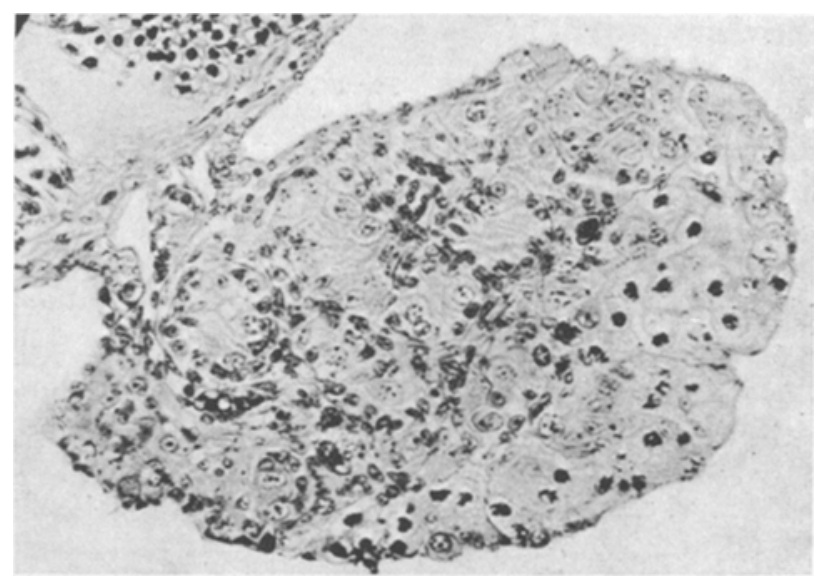

Fig. 36. Transection of a testis of an embryo of $14.0 \mathrm{~mm}$. C. L. The sex-coras are still attached to the well developed cortex, and are larger with the epithelial nuclei located basally near the basement membrane. No lumen is present. Alany oobytes in synizesis are in the cortex. $(x 220$.

differentiation of these elements apparently does not occur within the period of development considered in this paper. 
It is not unusual to find germ-cells in synizesis (oöcytes or spermatocytes ?) within the sex-cords as well as in the cortex. This is especially true in gonads which possess an unusually hypertrophied cortex. Such a high degree of intersexuality is seen in an embryo of $15.0 \mathrm{~mm}$. C. L (fig. 37). The cortex covers the anti-mesorchial surface of the testis and is sharply defined by indentations or grooves on the late ${ }^{m_{3}, l}$ walls of

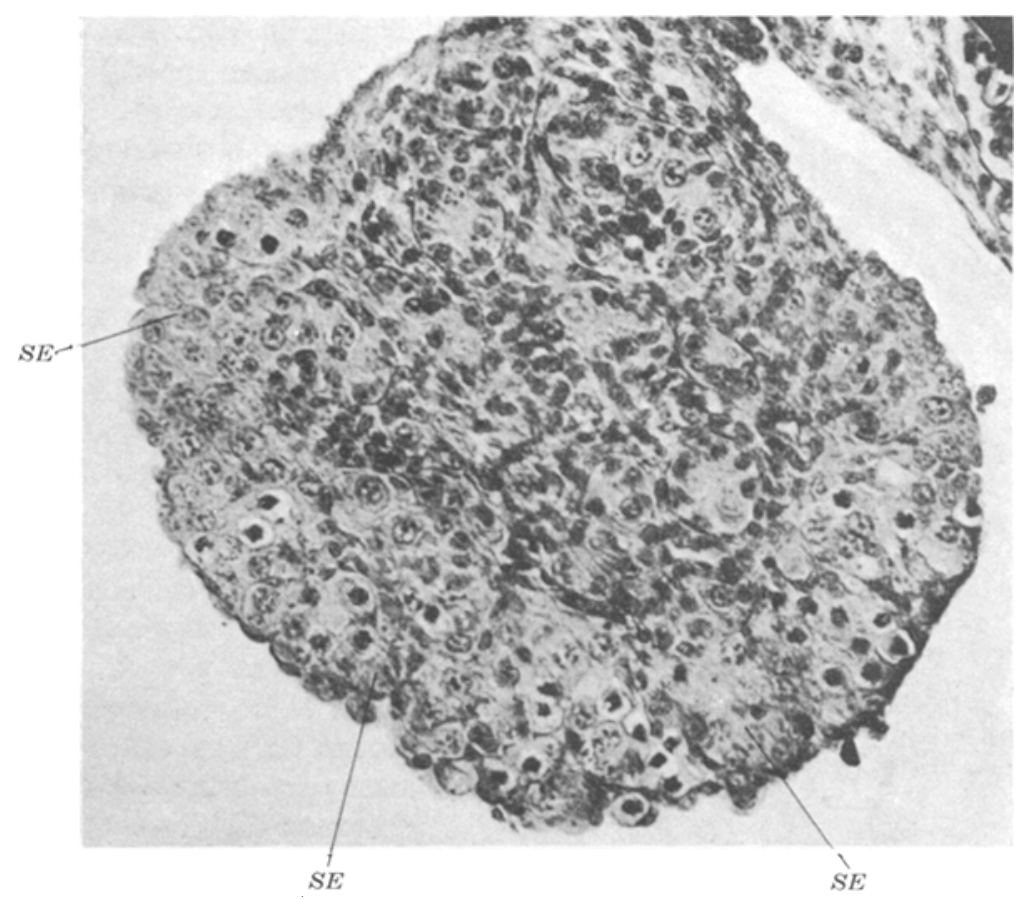

Fig. 37. Cross-section of a developing testis of an embryo of $15.0 \mathrm{~mm}$. C. L. An extreme development of the cortex is demonstrated. $S E$ Formation of new seminiferous tubules from the cortex. $(\times 274$.

the gonad. Sex-cords penetrate the stroma at various places throughout the gonad and maintain an intimate relation with the epithelium.

Regression of the cortex is accomplished in two ways. The oögonia may be forced outward into the coelom where they undoubtedly disintegrate soon afterwards. Irregularities in the surface of the gonad are very pronounced, some of the germ cells lying in the epithelium, some half in and half out of it, and others wholly in the coelomic cavity. The second mode of degeneration is observed in the primary oöcytes which are in the synaptic stages. The cells become flattened irregularly and the chromatin is squeezed out of the cells into the intercellular material and even into the coelom, where it must be resorbed (fig. 40). The cytoplasm of the cell disappears and is possibly resorbed and 
utilized by other cells. The chromatin is the last of the cell to disappear, and it is observed as a flattened, elongate darkened mass, which lies between two or three other normal germ cells. Degeneration through synizesis has previously been reported by KINGSBURY (1902) in Desmognathus. MrSIc (1923) has described the degeneration of the ovarian parts of the intersexual gonads of the trout as occurring in a caudo-

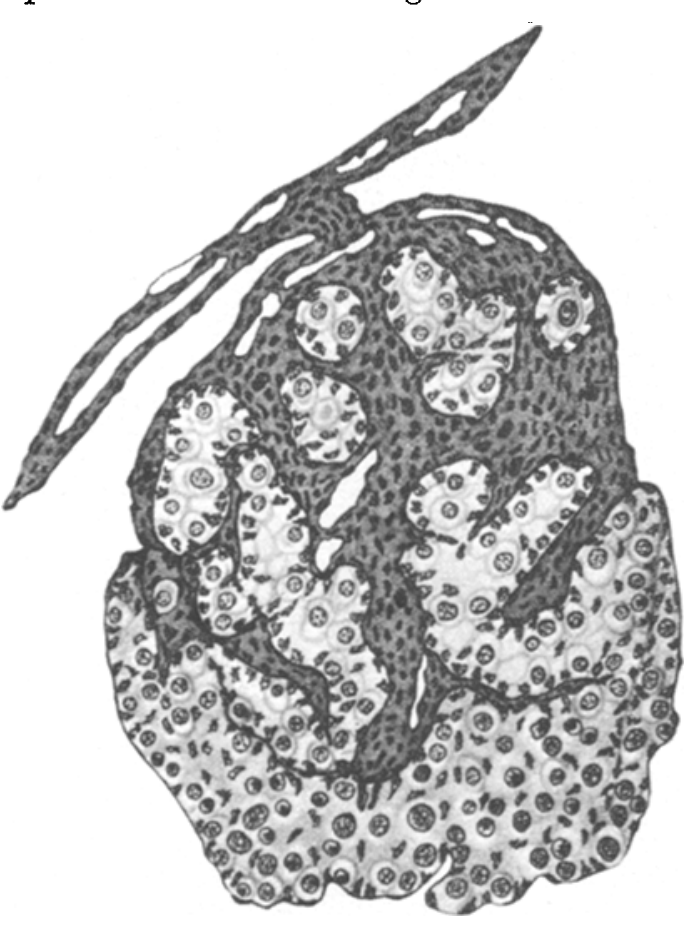

Fig. 38. Cross-section of a testis of an embryo of $20.0 \mathrm{~mm}$, G. L., showing the attachment of the seminiferous tubules to the reduced cortęx. $(x 176$. cephalic direction. There is no indication of an axial degeneration in any specific direction in the turtle, but there is a rather uniform disappearance of the cortex throughout the entire gonad.

A section through a testis taken shortly after hatching is shown in fig. 39. The cortex is now almost reduced to the usual single layer of epithelial cells and germ cells. Several of the oöcytes are in synizesis and at the beginning of the growth period. The germ cells of the seminiferous tubules are quiescent except for a few infrequent divisions.

In figs. 36,37 , and 38 , it will be observed that the sex-cords, at some places near the cortex, appear to be delimited from the cortex by a thin layer of connective tissue, the forming tunica albuginea. At other places, however, no such delimiting layer is observed. A close examination of the serial sections shows that the tunica albuginea never forms a continuous sheath about the sex-cords so that a minute testis is enclosed within a connective tissue capsule which separates the cortex from it. The sex-cords or seminiferous tubules are still connected with the epithelium which continues to addo those previously formed. Groups of epithelial and germ cells become separated from the cortex by the increasing number of stromal cells, so that it appears as if the cortex is actually proliferating its elements into the seminiferous tubules. It may be considered as a continuous sex-cord formation from the cortex by a process of down-growth of new elements which are added 
to the sex-cords laid down in an earlier period. This type of tubule formation in Amniotes has not been described previously, insofar as the writer is aware. All authors apparently have considered the growth of the sex-cords in size and number to be autonomous in nature. It is significant, however, that here we have evidence of a continuous proliferation of new seminiferous tubules from the epithelial cortex of the

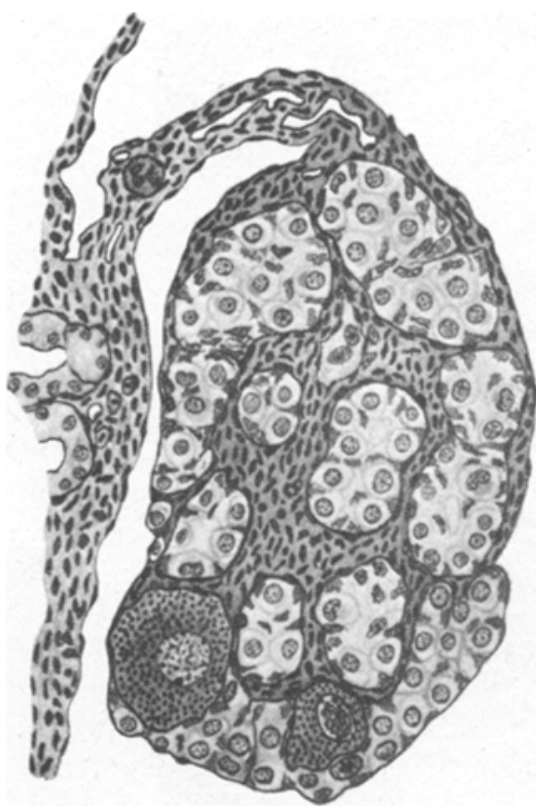

Fig. 39. Cross-section of a testis taken at hatching. The cortex is now reduced to almost a minimum. Two large oöcytes are present in the cortex. In adjacent sections the seminiferous tubules are attached to the cortex. $(x$ 176.) testis. The new tubules or cords are made up of numerous epithelial cells and germ cells which sink

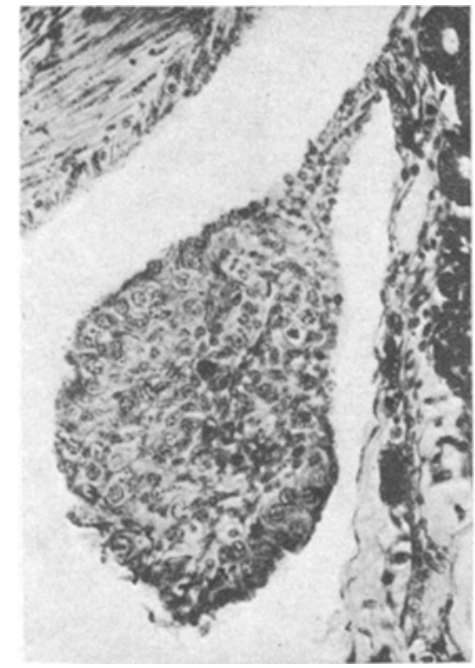

Fig. 40. Cross-section through the anterior part of a developing testis of an embryo of $17.0 \mathrm{~mm}$. C. t. The extreme development of the cortex is characteristic of both the anterior and posterior regions. An area of the cortex shows the degeneration of obcytes through synizesis and the chromatin is being extruded into the coelom. ( $x$ 188.)

into the stroma of the medulla at the junctions of the sex-cords and the cortex. This is one of the ways in which the ovarian homologue (cortex) is reduced in the testis.

c) Sex Reversal. In two male specimens, numerous oöcytes within the seminiferous tubules of the testes give indications of a sex-reversal from ovary to testis. The structure of the testis is somewhat abnormal, especially with respect to the numerous cavernous lymph spaces in the stroma which are more characteristic of the ovary. The germ cells of the seminiferous tubules are large and have plainly begun to grow; the nuclei are typically those of the growing oöcyte. The epithelial cells of the tubules are compressed around the growing oöcytes so as to resemble 
an ovarian follicle (fig. 41). The cortex remains as a thin layer on the antimesorchial surface of the testis and it connects with the seminiferous tubules directly. The presence of the oöcytes in the tubules and the attachments of the tubules to the cortex are ample evidence for the contention that the oöcytes and tubules were both of cortical origin, at least partially. The oviducts of these specimens are large and compare

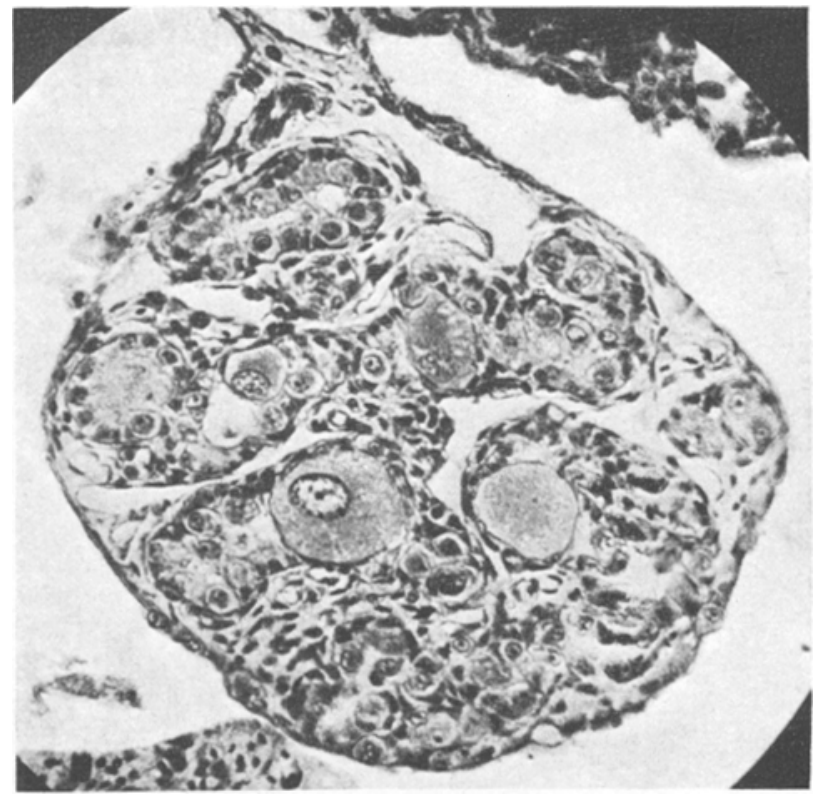

Fig. 41. Transection of a testis taken shortly after hatching. The presence of numerous oobcytes in the seminiferous tubules, the small number of seminiferous tubules, and the large spaces in the intertubular tissue suggest that this gonad has been produced by a transformation of ovary into testis. $(\times 236$.)

favorably with those of the female at hatching (fig. $28 \mathrm{~B}$ ). Unfortunately the cloacal portions were not sectioned and the condition of the copulatory organs could not be determined.

The above evidence brings us to the conclusion that an actual sex reversal has occurred in these cases, and that the original female complex has been superceded by the male type.

\section{Literature and Diseussion.}

\section{The indifferent gonads.}

The first to make observations upon the development of the urogenital system of reptiles was Braun (1877), who examined embryos of Platydactylus, Tropidonotus, Lacerta agilis, and Anguis fragilis. He 
concluded that the rete-cords were formed from evaginations of the walls of the MALPIGHIan corpuscles of the mesonephros. The proximal portions of these cords formed rete-cords, while, distally, the cords branched and passed into the sex-glands, where the branches developed into the sex-cords of the gonads. WELDon (1885), HofrmanN (1889), and Peter (1904), all using Lacerta agilis embryos, supported the views of BraUn. Felix (1906) also accepted this conception of rete- and sex-cord formation in reptiles. It has since been generally abandoned by investigators on other forms.

VoN MrHÁLKowicz (1885), also working on Lacerta, was of the opinion that the rete-cords were derived from the wall of Bowman's capsule by an evagination, but thought that the sex-cords were derived by a rearrangement of cells within the gonad. ALLEN (1905) retained this conception of rete-cord formation in part, but modified it slightly. In his opinion, only the proximal connections of the rete-cords with the MaLPIGHIan corpuscles of the mesonephros were formed in this manner. ALuEN was able to show that certain groups or cords of cells (funnelcords) formed the greater part of the rete-apparatus. The funnel-cords arise by invaginations of the peritoneum at the lateral edge of the genital ridges, from where they extend dorsally to contribute epithelial elements to the cortices of the adrenal glands. FIRKET (1914), who is supported by SwIFT $(1915,1916)$, has not agreed that the funnel-cords are the result of an invagination of epithelial cells, but, because of the nonattachment of similar cords to the peritoneum in the chick embryo, believes that they are formed by a condensation and organization out of differentiating mesenchymal cells of the nephrogenous tissue. Such an origin of the rete-cords is believed to occur in the Amphibia (WITSOHI, 1929a, 1929b; Cheng, 1932; Deal, 1930, and others). It seems to be agreed generally that, in mammals, the rete-cords are epithelial in origin (GoldsMith, 1932; StMkirs, 1923; ArLEN, 1904, and others).

In my material, the conditions are very similar to those described. by AlleN (1905) in Chrysemys marginata. The wax-model reconstructions made by him appear to be the most convincing evidence presented on the subject of rete-cord formation in Amniotes, although the evidence in Amphibia clearly supports WITSCHI's contentions. One point, however, has never been demonstrated with certainty and that is the method of establishment of the connections between the funnel-cords and the capsules of Bowman. I have observed nothing that would indicate a direct evagination or proliferation of cells from the wall of BowMas's capsule, nor a proliferation of cells from the funnel-cords to the walls of the corpuscles. The funnel-cords pass by the corpuscles so closely that they are almost in contact with them. In view of this fact, I prefer to think that the connections are made indirectly as a result of the growth of the MALPIGHIan corpuscle together with the possible incorporation 
of a few of the elements of the surrounding nephrogenous tissue, and the breaking away of the cords from their union with the cortical fundament of the adrenal. Rete-cord development in the Amniotes is not clearly understood, and should be reinvestigated thoroughly from a comparative point of view. Such an investigation obviously is not within the scope of this paper.

In regard to the formation of the sex-cords, JANOSIK (1890) was the first to observe that, in the chick, they arise as direct ingrowths of the germinal epithelium. FrRKET (1914), SwIFT (1915, 1916), and GoLDSMTTH (1928) have all agreed that this manner of sex-cord formation occurs in the chick embryo. Arren (1905, 1906), SIMkins (1925), and Srmkins and Asana (1930) also state that this is true for turtles and lizards. By far the majority of investigations on the early period of gonadogenesis in the Sauropsida subscribe to this view. Many writers (Satnmont, 1905; von Wintwarter et Sainmont, 1909; Popoff, 1909; ALLEN, 1904; and SIMkINs, 1923) claim that mammalian forms also exhibit the same process of sex-cord origin. The observations given above demonstrate that the sex-cords of $\mathrm{S}$. odoratus likewise originate as direct ingrowths or proliferations of groups of cells from the germinal epithelium. These cells either carry primordial germ cells inward with them, or they may grow around primordial germ cells which migrate directly into the deeper parts of the genital ridge.

On the other hand, some investigators (SKRoBaNsKy, 1903; WALDEYER, 1906; FeLIX, 1912; HARGITT, 1926; and GoLDSMITH, 1932) believe that, in the mammals, the sex-cords originate by means of a rearrangement of the cells of the epithelial blastema which lies under the germinal epithelium. Von MrHálkovioz (1885) described a similar formation of the sex-cords in Lacerta. In general, a very confused situation exists in the literature on this phase of germ-gland development, and one fails to find that "Most authors agree that the sex-cords are produced by this rearrangement of cells", as HaRaitT (1926) would have us believe for birds and mammals. It would appear that the development of the sex-cords is slightly different in various forms, as GouDSMITH (1932) suggests.

In S. odoratus, the epithelium of the genital ridge gives rise to all of the elements of the indifferent gonads, with the exception of the primordial germ cells. It has been established that the main portion of the rete-cords, the stroma, the sex-cords and their sheaths are all of epithelial origin. In regard to the origin of the proximal attachments of the rete-cords to the mesonephric corpuscles, it is probable that these connections are made simply by rearrangements of the elements concerned during the growth of the mesonephros and the funnel-cords. A definite inner core of epithelial cells does not appear before the origin of the sex-cords by an ingrowth from the epithelial layer as in 
the mammals, but the cells are proliferated from the epithelium in groups to become sex-cords at the same time that single cells break away to form the stromal elements.

\section{The morphology of sex differentiation.}

In 1906, FELIX reviewed the literature that had appeared before that time on sex-gland development in reptiles. BRAUN (1877), voN MIHácKovICZ (1885), and HoFFMANN (1889) investigated various phases in the morphogenesis of the urogenital system, but in the light of our present knowledge of gonadogenesis in other forms especially, the work of that time must be regarded as inadequate in detail. In general, the principal facts seem to agree with those known for other amniotes. Differentiation of the gonads occurs through changes in the epithelial covering. In the female, the epithelium thickens to produce the ovarian cortex, and the medullary cords acquire a lumen very early; in the male, the epithelium reduces to a single layer of cuboidal cells.

The most recent observations on the sex characters of developing germ glands in turtles were made by Aluen (1906) in Chrysemys marginata. He was unable to distinguish sex for some time (between the stages of 7.0 and $11.5 \mathrm{~mm}$. C. L.) following the formation of the sexcords. The early differences in ovary and testis are only relative, and may be briefly stated as follows: in the ovary, the sex-cords are narrow and widen to meet the epithelium with broad attachments; the germ cells are more numerous in the epithelium than in the sex-cords; the sex-cords break away from the epithelium when the carapace is about $14.0 \mathrm{~mm}$. in length. In the testis, the sex-cords are wide and attached to the peritoneum with an attachment of the same width as the cords until after hatching; the germ cells are more numerous in the sex-cords than in the epithelium. According to my observations, these characters are too variable to be of much value, although possible testes and possible ovaries could be distinguished for the first time at the same developmental stage as AlLeN (1906) did in Chrysemys. In view of the long indifferent period described by ALLEN as one in which sex remains indistinguishable and the fact that he describes the occurrence of numerous germ cells in the epithelium, it seems that this must be considered as an indication of an indeterminate period in the history of the testis where an ovarian character appears although possibly poorly developed. Apparently ALLEN chose to interpret the epithelial character of the testis as insignificant. No mention of the appearance of definite oöcytes in the testis of Chrysemys was made by ALLEN, but it is possible that a closer examination would reveal the female characters of the germ cells of the testis epithelium.

A similar condition to that described for Sternotherus is reported to occur in embryos of Calotes, a lizard of India, by Simkins and Asana 
(1930). Every germ-gland shows the presence of a well developed ovarian cortex containing maturing germ cells. At the time of publication, the authors were unable to give definite facts relating to the disappearance of the cortex, although they followed the development up to the time of hatching. Apparently sex differentiation occurs much later in Calotes than in Sternotherus, since they were unable to distinguish the sex of the embryos at hatching.

It has been of exceptional interest to find that, in Sternotherus, there is a prolonged indeterminate period, during which sex cannot be ascertained. On first thought, this period might be considered as a continuation of the usual indifferent period of gonadogenesis. It eannot be so thought of, however, because all embryos of the period exhibit the presence of both male and female gonadal tissues and a similar degree of development of the accessory sex organs. During the indeterminate period the sex differentiating factors are active, and continue their activity up to the $14.0 \mathrm{~mm}$. C. L. stage when the females are differentiated completely. The sex differentiation process continues until hatching in the male embryos. In the above description, it was definitely demonstrated that, in all cases, there is evidence of a juvenile hermaphroditism, or a transient period of bisexuality. Bisexual individuals are to be found throughout the egg stages, and by the time of hatching, they have become definitely male or female. The presence of oöcytes in the testes gives adequate testimony of the early bisexual nature of the male individuals.

With sex-cord formation during the indifferent period, a foundation for the development of a testis is laid down. This is characteristic of gonad development in all higher vertebrates. The sex-cords are the first structures to appear and are the morphological expression of the male character in both ovary and testis. It is a well-known fact that the ovary of amniotes is bisexual in its tendencies (Domm, 1927; LILIIE, 1927; WIтschi, 1929, and others). In the normal development of the ovary, the medullary cords, homologues of the sex-cords of the testis, degenerate after a period of transitory existence in early embryonic life. The persistence of the medullary cords for a relatively long period in the ovaries of Sternotherus embryos is likewise indicative of their bisexual nature.

Changes in the germinal epithelium immediately following sex-cord formation lead to the development of the ovarian cortex. In birds and mammals, the epithelium of the testis is very soon reduced to a single celled layer of mesothelium. However, in Sternotherus, the epithelium of every gonad thickens and produces a definite cortical region characteristic of the ovary. The simultaneous occurrence of cortex and sexcords gives the impression that the gonads are true ovaries. The subsequent history shows, however, that the cortex partially degenerates in prospective males and that the sex-cords develop resulting in testis 
formation. The cortex is the morphological expression of the female character in both testis and ovary, and its appearance in the testes of Sternotherus is further evidence of the presence of both male and female factors of sex determination and sex differentiation in all embryos.

The absence of a structure homologous to the ovarian cortex in the differentiating testis of the higher vertebrates has been described as a defect in the embryonic foundation, and as possibly responsible for the failure of experimentalists to produce sex-reversals from male to female (LILLIE, 1927). Acting upon this suggestion, HumpHREY (1929) was able to show that the testis of Ambystoma larvae often exhibits a secondarily produced cortex; the cortex present then serves as an embryological foundation necessary for the production of a female individual from a male. It is obvious that the bisexual character of the testes in Sternotherus furnishes a morphological foundation or basis for a possible sexreversal of a zygotic male in the female direction. The morphological processes involved in testis formation parallel those which must occur during a reversal from ovary to testis. From a like viewpoint, it may be stated that the development of the ovary parallels the morphological changes which must occur in a reversal from testis to ovary. Both testes and ovaries develop out of a bisexual primordium, and the bisexuality of the early gonads furnishes a morphological foundation for the eventual formation of either sex.

JoRDAN (1922) is of the belief that all embryos of higher vertebrates are potentially hermaphroditic. In his discussion of hermaphroditism in man, he states that "the definitive sex of an individual results from the inhibition and later suppression of the opposite sex primordium". And again that, "Amphibia would seem to furnish the phylogenetic group corresponding to the ontogenetic stage in mammals whereupon the fundamental bisexual (indifferent) primordium, having its separate germinal factor, is superimposed a condition more directly under the control of a special sex chromosome". It is apparently unnecessary to look that far back in the phylogenetic line for a group of vertebrates which furnishes evidence that the embryo is potentially bisexual or hermaphroditic, for the Chelonia will amply fulfill the requirements of such a demand. It is well-known that the Chelonia in their embryonic development exhibit many resemblances to the Mammalia (ALLEN, 1905), especially in regard to the formation and arrangement of the rete-cords and sex-cords, the early appearance of the amnion, and the development of the adrenal glands. On the other hand, it is obvious that the cortex of the chelonian ovary is similar to the cortex of the amphibian ovary, except for its late appearance after sex-cord formation.

It was stated above that new seminiferous tubules were added to the medullary area of the testis as the cortical area degenerated. This seems to be contrary to previous investigations on the development of 
the seminiferous tubules, which are considered as formed out of the sex-cords and separated from the epithelium by the development of the tunica albuginea. Growth of the tubules has heretofore been thought of as autonomous in nature. Continuous tubule formation is significant since it demonstrates: 1) the accuracy of the fundamental observation that the germinal epithelium is responsible for the formation of the seminiferous tubules, and 2) that ingrowth of epithelial cells is a characteristic activity of the germinal epithelium. HЕтт (1930) has shown that, in several mammalian species, the germinal epithelium of the gubernaculum testis tends to grow inward to produce tubule-like structures, which he regards as homologous to the secondary cords of the ovary. There are two interpretations of the significance of this successive production of tubules from the epithelium. First, it is homologous to the formation of the ovarian follicle, as HETT has concluded; and second, it represents a fundamental ability of the germinal epithelium to produce continually either follicles or seminiferous tubules, for the constituents are of the same origin. Which will form depends upon the surrounding medium once sex has been determined. This explains the production of seminiferous tubules in the right ovary of the sinistrally ovariotomized hen (Domm, 1927; Berort, 1926; GraY, 1930). Since ovariectomy removes the inhibitor of the development of the right ovary and the active female elements, the rudimentary environment of the right ovary is such that the proliferations from the germinal epithelium respond by a differentiation in the male direction.

3. Sex differentiation in the germ cells.

The morphological similarity of all germ cells in the early gonads during the period of active germ cell division gives no evidence as to their sex. Spermatogonia and oögonia are structurally alike and it is impossible to distinguish them until oöcyte formation, except on the basis of their position in the medulla and cortex, respectively. As early as the $8 \mathrm{~mm}$. C. L. stage, certain of the germ cells of the cortex enter a contraction stage which is characteristic of the maturing germ cell. This is regarded as the beginning of the definitive female cells, and from this time on the germ cells of the cortex are to be looked upon as oögonia or oöcytes, as the case may be. Likewise the germ cells of the sex-cords may be considered as spermatogonia. The presence of spermatogonia in the medulla and of oöcytes and oögonia in the cortex is additional proof of the bisexual character of the gonads of embryos of this species. Oöcytes are present in the cortex of all gonads examined beginning with the $9 \mathrm{~mm}$. C. L. embryos with the exception of one individual which was probably retarded in its development.

In his study of sex reversal in Rana sylvatica tadpoles developed in high temperature experiments, Wirschi (1929c) observed that the oögonia of the cortex of the ovary were transformed into spermatogonia 
as they passed into the sex-cords of the medulla. A similar process occurs in the development of the testis of Sternotherus as the cortex is transformed into seminiferous tubules. There is but one alternative, namely, that the germ cells of the cortex which have not already entered the oöcyte stage are undifferentiated or indifferent germ cells, and as such are able to become spermatogonia. The first interpretation is favored since it is obvious that many of the germ cells of the cortex are already female auxocytes, and it is therefore concluded that the gonial cells are likewise differentiated in the female direction. With this in mind, it would appear that the ooggonia do become spermatogonia when included in the cords of the medulla of the gonad. Nevertheless, the fact that growing oöcytes appear occasionally in the medulla indicates that the transformation is not always successful. The conclusion that the germ cells (of primordial germ cell origin) have the potential ability to differentiate into either male or female elements is inescapable. This is especially true in cases of juvenile hermaphrodism where sex determination is not directly under the stringent control of the chromosomal mechanism and the zygotic constitution.

If it is assumed that all of the germ cells are potentially bisexual, some factor or factors must then determine what line of development the germ cells will follow. Two interpretations are possible: the cells may differentiate as a result of their own inherent tendencies, or because of certain factors operating in the surrounding environment. There is no direct evidence that the gonial cells of the cortex are inherently different in the early stages of development with the appearance of the cortex and medulla. It is possible that an unequal distribution of chromatin or of cytoplasm would produce such a differentiation in the constitution of the cells, but proof is wanting. If the germ cells of both cortex and medulla arise from the same embryonic source, in this case the primordial germ cells, they would be expected to have the same inherent qualities present in the zygote. Consequently, the differentiation from primordial germ cell to spermatogonia or oögonia must depend on other qualities, namely, their relation to the surrounding medium, which in this case must be the cortex and the medulla of the gonad. It seems that the cells are not zygotically determined as male or female, although such a condition would make the environmental effect of the cortex and medulla more obvious. The germ cells are indifferent as to sex and only with the appearance of the cortex and medullla does differentiation occur in a female and male direction respectively. They are potentially capable of differentiating in either direction depending upon their gonadal position. Sex differentiation of the germ cells is comparable to any embryonic differentiation and is subject to regulation by extrinsic factors, even though the extrinsic (in this case, medulla and cortex) may be determined zygotically. 
In certain races of the Amphibia in which the testes differentiate early [WITSCHI (1921, 1929)], some of the primordial germ cells fail to reach the medulla and are left in the germinal epithelium. These develop into primary oöcytes at the same period that the primary set of oöcytes enter the synaptene stages in the ovary. Such gonads are hermaphroditic for a brief time but the oöcytes soon disappear. On the basis of this evidence and that derived from a study of the undifferentiated races (with which the general features of sex differentiation in Sternotherus coincide), WITSCHI (1931) suggests that the cortex and medulla produce "sex-specific morphogenetic substances" (cortexin and medullarin) which are influential in sex differentiation. The cortex is the center of localization of the female-differentiating system and the medulla the center of the male-differentiating action. SwINGLE (1926) has shown that the progonads of bull-frog tadpoles (sexually neutral according to him) become testes with the appearance and development of the sex-cords. Domm (1929) interprets the results of his sinistral ovariectomy experiments on the chick, in which he obtained spermatogenesis following a sex reversal from female to male, in terms similar to WITScHr's hypothesis for the Amphibia: "That primordial germ cells are necessary for gametogenesis, that when they become incorporated in the cords of the medulla they produce spermatogenesis and when in the cortical elements of the gonad they produce oögenesis". CREw (1923), in agreement with this, suggests that the cytological features of both oöcytes and spermatocytes may be dependent upon the balance of antagonistic physiological factors which are determined by the sex chromosome complex of the soma or locally through the action of hormones, and thus may be capable of inversion. The observations on the cytological features of sex differentiation in Sternotherus are wholly in harmony with these conceptions.

It must be remembered that it is not impossible for some of the germ cells of the medulla to become oöcytes. This offers no difficulty for such an hypothesis for it is very likely that these cells once were located within the cortex and there became female in nature after which they were translocated into the sex cords. The attachments of the sex-cords to the cortex furnishes a morphological means for such translocations.

\section{The mechanism of sex determination.}

As stated by WITSchI (1929), "Pure observation of the normal developmental processes proves absolutely unsuited to elucidate the question how the alternative between the two possible sexes is decided, i. e., how the sex is determined. Only experiments can possibly reveal what part is played by hereditary factors and which are the physiological realizators to stimulate the morphological differentiation". In the absence of experimental data, it would be mere speculation to 
attempt a statement as to the nature of the sex-determining factors and the sex-differentiating mechanisms at work in the turtle embryo. It is clear, however, that sex-differentiation in Sternotherus embryos is of a long duration during which both male and female sex-differentiating substances (genic, hormonic, morphogenetic, or metabolic ?) are operating. What these substances are is not certainly known at present and much speculation has been prevalent among investigators of the problem.

By means of numerical, genetical, cytological, and morphological studies, it has been definitely established that the determination of sex is an hereditary phenomenon which follows the normal MENDELian laws of heredity. In this investigation it has been shown that the sex primordia of the embryo are bisexual in character and that each embryo is capable thereby of developing into either male, female, or abnormally into hermaphroditic adults which have not been observed. The number of recorded cases of intersexual organisms, experimentally produced sex inversion in various groups of organisms, and embryological evidences lead to the conclusion that hereditary factors for the production of both sexes are present in every fertilized ovum which is then genetically bisexual, and potentially of either sex.

The several concepts which have been advanced as the exact hereditary mechanism responsible for the transmission of sex all agree upon one essential principle, namely, that it is purely quantitative in all of its relations. The physico-chemical theory of sex determination of JoYETLaverane (1931), the basal-metabolism theory of RIddLe (1916 etc.), and HeRTwig's theory assuming chromosomal-cytoplasmic interaction are all in agreement with the genic (Morgan, BrIDges, WILson and Schrader), and the genic-hormonic (Goldschmidt and WitschI) theories as far as the quantitative relations of the sex determinators are concerned. The differences are mainly in the assumptions (none entirely without evidence) as to the nature of the determinators and their location.

Because sex differentiation in the turtle so closely parallels sex differentiation in the undifferentiated races of the Amphibia, it seems probable that WITSCHI's analysis of these forms would be the most applicable of the above theories to the mechanism of sex determination in the turtle.

It was shown by WITschi (1924) that the sex chromosomes of R. temporaria were of the $\mathrm{XX}-\mathrm{XY}$ (Drosophila) type. In his explanation of the mechanism of sex determination (1929 d), he accepts the genetic formulae of Morgan and Goldschmidt as MM (autosomes), FF (Xchromosomes) for females, and MM (autosomes), Ff (X-and Y-chromo. somes respectively) for males of the rudimentary hermaphrodites. The formulae for the gametes are MF for the eggs, and MF (gynosperms) and Mf (androsperms) for the two types of sperms respectively. The 
quantitative relations of these factors may be expressed as $\mathrm{FF}>\mathrm{MM}>\mathrm{F}>\mathrm{f}$. As WITsChI says, rudimentary hermaphrodism is unstable and is especially interesting because "the frequent cases of sex reversal under natural and experimental conditions indicate that the genotypical sex determination is not firmly established but still leaves open possibilities for the action of phenotypical agents". In the absence of genetical data and knowledge of the chromosome complex in turtles, I am inclined to accept the above analysis as applicable to the known morphological details of sex differentiation as determined in this study. Further experimental analysis is, of course, desirable. The juvenile hermaphroditism observed in previous investigations (OKKELBERG, 1921; MřsIC, 1923) has led the authors to assume that the genetic sex factors for maleness and femaleness are in a state of near balance and thus both are expressed in the morphogenesis of sex.

5. The modification of sex.

Recent advances in the study of sex differentiation and sex determination have been made principally by means of experimental modification of sex. The results obtained by WITschI (1914-1929) in the Amphibia are of especial interest. By the cultivation of tadpoles of $R$. temporaria and $R$. sylvatica at high temperatures of $27^{\circ}$ and $32^{\circ} \mathrm{C}$. he has been able to effect a sex reversal from female to male in $100 \%$ of the cases. The conclusion is reached that the female-differentiating substance is destroyed or suppressed by high temperature while the male character is allowed to develop in the absence of the inhibiting action of the female differentiator. WITSCHI (1927), WrTSCHI and McCurdY (1929), and BuRns (1925, 1930) have produced sex reversal in salamanders and frogs by uniting larvae in parabiosis. Such a union of individuals produces an effect similar to that illustrated in the free-martin (LILLIE 1917), in which the male is always dominant. BuRNs (1930) has offered evidence that transformation may also occur from male to female. $\mathrm{He}$ states, with respect to parabiotic Ambystoma larvae, that, "The present results compare better with results from transplantation of the embryonic preprimordium (HUMPHREY), where there is primary (zygotic) differentiation, followed by transformation effects upon the female gonad (whether graft or host). They differ from HuMpHREY's results in that there are marked reciprocal effects on the male, culminating in several undoubted cases of female dominance; and in the appearance of positive evidence of transforming influences prior to morphological differentiation". HUMPHREY's (1929) results, after orthotopic implantation of a gonadic preprimordium have shown that the male gonads tend to be more influential in modifying or reversing the development of the ovary. He suggests that the dominance of the male is probably the result of an earlier hormone production in the testis. WiTschI (1931) shows in an analysis of heterosexual parabiosis that the cortex and 
medulla act as inhibitors upon each other's development in the cu-twins, although the cortex is less powerful; that the causal agents of the inhibitory actions spread with falling gradients of efficiency from the gonads to the body of the cotwin; that the medullar development in ovaries is due to an autonomous reaction of the rete ovarii, - not to stimulation from the male twin but to the inhibition of the cortical control; and that the interactions of the gonads of the twins occur by means of morphogenetic substances, medullarin and cortexin, which spread through the tissues. These findings are especially significant since they demonstrate the relations of medulla and cortex and their mode of action in sex differentiation.

A number of workers have succeeded in inducing sex reversal from the female to male by the removal of the left ovary of the female bird [BenoIT (1923, 1926, 1932); ZaWadowsky (1926); Domm (1927, 1929)]. In these cases, made easier because of the asymmetrical gonadal development, the right ovary undergoes a compensatory hypertrophy and may assume the structure of a testis in which spermatogenesis is complete [Domm (1929)]. Other possibilities are realized in that the right ovary may become a sterile testis, an ovotestis, or an ovary in which complete and normal oögenesis may occur. The accessory and secondary sex characters also undergo changes which parallel those of the gonad. LILLIE (1927), in an analysis of the available information on sex inver. sion and bisexuality of the female bird, concludes that, "sporadic cases of sex-inversion cannot be used for interpretation of normal sex conditions until we know more about their genetics, and that the experimental transformation of the normal hen in the male direction is a consequence of the embryologically determined, but variable, sex equipment of the female".

It has been pointed out that the structural alterations which appear during sex differentiation in Sternotherus males parallel those to be expected during a reversal of sex from an ovary to a testis. It is impossible to say at this time that an actual sex reversal has occurred in all cases of testis development, since the material examined does not give sufficient numerical data to permit an accurate determination of the sex ratio at hatching. Two specimens show an exceedingly large number of oöcytes within the seminiferous tubules and the oviducts are developed to a degree comparable to that of the oviduct of the normal female. These specimens are exceptions and may reasonably be considered as the result of a transformation of a zygotic female to a male. Unfortunately, little is known about the normal sex ratio in turtles. The only available data are those obtained at the United States Fisheries Biological Station at Beaufort, North Carolina on the diamondback terrapin. HILDEBRAND (1928) states that an unusual sex ratio - I male to 6.4 females - appears in Carolina terrapins grown in 
captivity. In hybrid lots the males were much more numerous, although the normal sex ratio was undetermined. In 1927, out of 1300 mature animals, only 242 males were present, - a ratio of 1 to 4.4. He further notes that if the expected $1: 1$ ratio occurs among young terrapins, it would then appear that the males failed to attain maturity either as a result of differential mortality or because of the custom of selecting the larger and stronger animals at about one year of age. Preliminary collections of adult musk turtles from nature show a predominance of females (RIsLey, 1933). Future investigation must be carried out in order to determine the sex ratio at hatching and the embryonic mortality rate in a natural environment, since there are some indications that an abnormal sex ratio may exist. Rather than assuming that all testes are produced from an ovary by a process of sex-reversal, it is concluded that the female differentiators produce a cortex early in the development of the testis. Testis differentiation then proceeds out of a bisexual primordium, and is characterized by the transformation of the ovarian cortex into seminiferous tubules of the medulla.

Since the embryos used in this study were kept under laboratory conditions, it has been impossible to determine satisfactorily whether or not the bisexual condition has been superimposed upon the male embryos as a result of environmental disturbances in the sex-differentiating mechanism. It is difficult to believe that the change from a normal situation in the open to one indoors with the retention of the same medium and corresponding temperature conditions would so alter the supposedly stable zygotic sex factors. HumpHrey (1929) suggests that the growth of the cortex in male larvae of Ambystoma may be due to the laboratory environment. That the embryo is influenced by nutritional alterations does not appear to be tenable. It is possible, however, that the necessary conditions for the production of the cortex in the male embryos may have been due to environmental conditions. If such is the case, the exceptional cases of apparent sex reversal from female to male are inexplicable. At the present time, I believe that the sex differentiation described is entirely normal, and this belief is substantiated in part by a few embryos taken from natural surroundings. The sex reversals reported may be due to high temperature which occasionally reached $37^{\circ} \mathrm{C}$. in the room in which the embryos were kept. Since this temperature was not constant, it may have influenced only a few of the more susceptible embryos.

No adult Sternotherus hermaphrodites have ever been reported and I have found none. Three cases of adult intersexuality have been reported in turtles and two in lizards. In a male of Emys europaea, MatTHEY (1927) found one ovotestis present, and was of the opinion that the oöcytes present were the remnants of an earlier intersexual condition. He further suggested that this case represented an epigenetic inter- 
sexuality due to a temporary weakening of the tendency to masculinization, probably under the influence of external factors. F'ANTH:M (1905) described two intersexual adult specimens of Testudo graeca. Both were males with well-developed oviducts, and all four testes were active and contained many spermatozoa. An ovotestis was present on the left side of one individual. JACQUET (1895) described a similar case in Lacerta anguis, and LANTz (1923) discovered an hermaphroditic male Lacerta saxicolis. It is significant that these are all male specimens.

The primary object of this paper has been to point out the juvenile hermaphrodism of the turtle embryo, rather than to explain sex determination which can only be done by the application of experimental methods. It seems possible that the reptiles may furnish additional material with which we may be able to obtain a deeper insight into the phenomena of sex determination and sex differentiation. Whether the material will lend itself readily to experimental procedure is yet to be ascertained. Further investigations must be undertaken in order to determine many of the fundamental facts which underlie the study of sex. The absence of information on the normal sex ratio, the sex chromosome complex, sex inheritance, somatic sex characters, and other similar features of sex investigation does not enable us to begin experimental work immediately. The normal must be ascertained before experiments can be adequately planned. Whether or not geographical races of Sternotherus which differ in the time of sex differentiation exist, as WITSCHI and SwINGLe have found in the Anura, also remains to be determined. Sex differentiation occurs slowly and it is to be expected that the material will show interesting results in case satisfactory experimental methods are found with which to attack the problem.

6. The continuity of the germ cells.

The study of germ cell history has never been carried through the entire life history of any reptilian species. The closest approach was a study on Chrysemys by ALLeN (1905). Since that time no study of the germ cells has been continued beyond the time of hatching. In regard to the embryonic origin of the germ cells, all authors, except Dustin (1910), von Berenberg, Gossler (1914), Simkins (1925), and Simkins and AsANa (1930), are agreed that the germ cells are segregated early in the embryo and undergo the normal differentiations in the course of becoming the definitive germ cells. Such a conception is supported in this study. No evidence has appeared which could be interpreted as indicating a complete degeneration of the primordial germ cells or a formation of new germ cells through a differentiation of epithelial cells as held by the above mentioned authors. It is unquestionably true that the germ cells of the cortex undergo degeneration while in the stage of synizesis, and also that some primordial germ cells degenerate after reaching the gonad and before ever dividing. Such degeneration is 
never complete enough to warrant a statement that the primordial germ cells never form the definitive germ cells of the gonad of the newly hatched animal. If a transition of epithelial cells into germ cells occurs, it could hardly escape observation, especially during the $7 \mathrm{~mm}$. C. L. stage just preceding the active multiplication stages of the primordial germ cells in the formation of the ovarian cortex and during the later stages following oöcyte degeneration.

It is evident that epithelial cells differentiate and enlarge but it must be emphasized that these elements cannot be construed as representing intermediate stages in the transformation of epithelial elements to reproductive cells. Simply because a cell becomes larger does not mean necessarily that it is becoming a germ cell for three pertinent reasons: (1) When an epithelial cell enlarges it may be preparing to divide, and such initial changes in mitosis parallel the early changes described by the supporters of the epithelial origin of germ cells. (2) An enlarging and elongated cell may be differentiating into an epithelial cell of a seminiferous tubule or of an ovarian follicle. (3) Enlarging nuclei and clearer cytoplasm in a basal cell of the epithelium may just as well indicate a transformation into a stromal element.

Whether or not the epithelial cells are able to produce new seasonal proliferations of germ cells remains problematic. The retention of some germ cells of primordial germ cell origin within the surface epithelium of the ovary and the testis at hatching makes the possibility of germ cell origin from epithelial cells during the growth of the germ glands even more doubtful. Interesting and fundamental facts may appear as a result of future studies of the germ cells in adults and in younger immature specimens. In any case, the germ cell line ("Keimbahn") in Sternotherus is continuous from the time of gastrulation to hatching.

\section{Summary and Conclusions.}

(1) The early period of gonadogenesis is characterized by a rapid proliferation of epithelial elements which give rise to the sex-cords and to the stromal elements of the gonad. Sex-cords proliferate inward from the epithelium as groups of cells containing one or more primordial germ cells. Stromal cells are derived from single cells which proliferate inwards away from the epithelium between the sex-cords.

(2) The rete-apparatus is formed mainly from the so-called "funnelcords" of ALLEN (1905), which probably originate from the epithelium. These cords also contribute cells to the cortical fundament of the adrenal glands. Connections of the rete-cords with the mesonephric tubules are established by contacts made by the funnel-cords with the MAcPIGHIan corpuscles during the growth of the mesonephros and the breaking away from the adrenal primordia. Sex-cords grow downwards and 
establish connections with the rete-cords. Part of the rete-cords may be incorporated within the gonad as sex-cords.

(3) Throughout the indifferent period, the primordial germ cells undergo divisions at a slow rate. They are distributed in the sex-cords and in the epithelium in approximately equal numbers.

(4) At the close of the indifferent period, the germ cells of the epithelium begin to divide rapidly, and produce a thickened cortex which covers a medullary area of stroma and sex-cords $(7.5 \mathrm{~mm}$. C. L. embryos). This marks the beginning of sex differentiation during which there is an indeterminate period when both male and female characters appear and the sex of the embryo remains in question.

(5) The indeterminate period (7.5 to $11.0 \mathrm{~mm}$. C. L. embryos) is described as a period of bisexuality, comparable to juvenile hermaphrodism, rudimentary hermaphrodism, and transient intersexuality of other authors. The oviducts and the phallus are present in a similar degree of development in all individuals. Male and female gonadal characters (the medulla and cortex, respectively) are present in every individual but vary in their degree of development.

(6) Im embryos of 11.0 to $14.0 \mathrm{~mm}$. C. L., it is possible to determine that some individuals will develop into the male or the female sex on the basis of the relative amounts of medulla and cortex, respectively. In other individuals, a typical bisexual condition is present.

(7) Testes or ovaries may first be distinguished with certainty in embryos of $14.0 \mathrm{~mm}$. C. L., when, in the case of the ovary, the medullary cords break away from the epithelial cortex and begin to degenerate. In the testis, the sex-cords retain their attachments with the cortex, and the cells of the cortex become rearranged and differentiated to form new and additional seminiferous tubules. The germ cells of the cortex which do not degenerate become located in the sex-cords where they continue to develop as oöcytes or as spermatogonia.

(8) Regression of the oviducts in the males and the phallus in the females begins approximately at the same time (14.0 mm. C. L. embryos). During the indeterminate period, macroscopic observations show that the gonads are female (protogynous) in shape and size.

(9) Normal maturation stages appear in the germ cells of the cortex as early as the $8.0 \mathrm{~mm}$. C. L. stages, and are found in nearly every germgland from that time to hatching. The maturation stage (synizesis) is confined to female auxocytes. While in synizesis, numerous oöcytes degenerate before entering a pachytene stage. The pachytene threads appear shortly before hatching, when the oöcytes enter the growth period. The follicle cells of the ovary are derived from elements of the epithelium.

(10) Germ cells of primordial germ cell origin remain in the surface epithelium of both the ovary and testis at the time of hatching. 
(11) The presence of an excessive number of oöcytes in the seminiferous tubules of some of the testes examined and the female character of the oviducts seems to indicate that a sex-reversal from female to male has occurred in some specimens, possibly due to the influence of laboratory conditions.

(12) The germ cells present in newly hatched individuals are derived from primordial germ cells, which are identical with cells of the primitive knot and are therefore segregated at an early period of development. There is no evidence that epithelial or somatic cells become differentiated to form cells of reproductive function.

(13) The sex-cords and the medullary-cords are homologous structures of the male and female sex-glands, respectively. The continuous production of sex-cords from the cortex of the testis is homologous to the formation of the ovarian follicles, both morphologically and in time of development.

(14) During the bisexual period of development, the female- and male-differentiating factors are apparently in a condition of near balance and the embryos are in a state of fluctuation between two alternative directions of development. Eventually one or the other factor takes the lead and the other factor is inhibited or suppressed so that the individuals become definitely male or female. What the determining factors in the differentiation of sex are is unknown at present. It is probable that they are zygotic, acting through a quantitative influence of enzymes, hormones, or morphogenetic substances upon the cortex and medulla of the gonad and upon the germ cells therein contained.

(15) A morphological basis or embryonic foundation for the development of either sex, or of hermaphroditic adults, is present in every individual, and sex reversal may therefore take place in either direction. Theoretically, in cases of near balance of the zygotic sex factors, sex is unstable in character, and it should be possible to produce sex inversion in these embryos by the use of proper experimental methods.

(16) The close resemblance of sex differentiation in Sternotherus to sex differentiation in the rudimentary hermaphroditic races of Amphibia as described by Wiтschi leads the author to accept his theories of sex determination and sex differentiation until experimentation can throw further evidence upon their applicability.

\section{Literature Cited.}

Allen, B. M. : The embryonic development of the ovary and testis of the mammalia. Amer. J. Anat. 3 (1904). - The origin of the sex-cords and rete-cords of Chrysemys. Science (N.S.) 21 (1905). - The embryonic development of the rete-cords and sex-cords of Chrysemys. Amer. J. Anat. 5 (1905). - The origin of the sex cells of Chrysemys. Anat. Anz. 29 (1906). - Benoit, J.: Transformation experimentelle du sexe par ovariotomie précoce chez la poule domestique. C. r. Acad. Sci. Paris 177 
(1923). - Études histologiques de la glande génitale droite de la poule ovariotomisée en un testicule. C. r. Acad. Sci. Paris 182 (1926). - Berenberg-Gossler, H. von: Über Herkunft und Wesen der sog. primären Urgeschlechtszellen der Ámnioten. (Vorl. Mitt.) Anat. Anz. 47 (1914). - Bridges, C. B.: Sex in relation to chromosomes and genes. Amer. Naturalist 56 (1925). - Braun, M.: Das Urogenitalsystem der einheimischen Reptilien. Arb. zool.-zoot. Inst. Univ. Würzburg 4 (1877). - Burns, R. K. Jr.: The sex of parabiotic twins in Amphibia. J. of exper. Zool. 42 (1925). The process of sex transformation in parabiotic Amblystoma. I. Transformation from female to male. J. of exper. Zool. 55 (1930). - Cheng, T. H.: The germ cell history of Rana cantabrigensis BAIRD, 1932. (In press.) - Crew, F. A. E.: Studies on Intersexuality. II. Sex reversal in fowl. Proc. roy. Soc. Lond. B. 95 (1923). Deal, R. E.: The development of sex characters in the tree frogs. Anat. Rec. 48 (1931). - Domm, L. V.: New experiments on ovariotomy and the problem of sex inversion in the fowl. J. of exper. Zool. 48 (1927). - Spermatogenesis following early ovariotomy in the brown leghorn fowl. Arch. Entw.mechan. 119 (1929). Dustin, A. P.: L'origin et l'évolution des gonocytes chez les Reptiles (Chrysemys marginata). Archives de Biol. 23 (1910). - Fantham, H. B.: On hermaphroditism and vestigial structure in the reproductive organs of Testudo graeca. Ann. a. Mag. Natur. Hist. 16 (1905). - Felix, W. and Bühler, A.: Die Entwicklung der Keimdrüsen und ihrer Ausfuhrgänge. O. Hertwigs Handbuch der vergleichenden und experimentellen Entwicklungslehre der Wirbeltiere, Bd. 3 (1). 1906. - Felix, W.: Development of the urogenital organs. In KHIBEL and MaLL's Manual of Human Embryology, Vol. 2. 1912. - Firket, J.: Recherches sur l'organogénèse des glandes sexuelles chez les oiseaux. Archives de Biol. 29 (1914). - Goldschmidt, Richard: Analysis of Intersexuality in the Gipsy-Moth. Quart. Rev. Biol. 6 (1931). - Die zygotischen sexuellen Zwischenstufen und die Theorie der Geschlechtsbestimmung. Erg. Biol. 2 (1928). - Goldsmith, J. B.: History of the germ cells in the domestio fowl. J. Morph. a. Physiol. 46 (1928). - The history of the germ cells in the albino rat (Mus norvegicus albinus). Trans. amer. microsc. Soc. 51 (1932). - Gray, J. C.: The development, histology and endocrine functions of the compensatory right gonad of the hen. Amer. J. Anat. 46 (1930). - Hargitt, G. T.: The formation of the sex-glands and germ cells of mammals. II. The history of the male germ cells of the albino rat. J. Morph. a. Physiol. 42 (1926). - Hellmuth, K.: Morphologische Studien über Kloake und Phallus der Amnioten (Fleischmann): Die Schildkröten und Krokodile. Gegenbaurs Jb. 30 (1902). - Hertwig, R.: Über den derzeitigen Stand des Sexualitätsproblems nebst einigen Untersuchungen. Biol. Zbl. 32 (1912). - Über den Einfluß der Überreife der Eier auf das Geschlechtsverhältnis von Fröschen und Schmetterlingen. Sitzgsber. bayer. Akad. Wiss., Math.-physik. Kl. 1921. - Utber experimentelle Geschlechtsbestimmung bei Fröschen. Sitzgsber. bayer. Akad. Wiss., Math.-physik. K1. 1925. - Hett, J.: Vergleichende Untersuchungen über das persistierende Keimepithel des Hodens einiger Säuger (I. Mitt.). Z. mikrosk.-anat. Forsch. 20 (1930). - Vergleichende Untersuchungen über das persistierende Keimepithel des Hodens einiger Säuger. (2. Mitt.) Z. mikrosk.anat. Forsch. 28 (1932). - Hildebrand, S. F.: Review of experiments on artificial culture of the diamond-back terrapin. Bull. Bur. Fisheries 46 (1929). - Hoffmann, C. K.: Zur Entwicklungsgeschichte der Urogenitalorgane bei den Reptilien. Z. Zool. 48 (1899). - Humphrey, R. R.: Studies on sex-reversal in Amblystoma. I. Bisexuality and sex-reversal in larval males uninfluenced by ovarian hormones. Anat. Rec. 42 (1929). - Studies on sex-reversal in Amblystoma. II. Sex differentiation following orthotopic implantation of a gonadic preprimordium. J. of exper. Zool. 53 (1929). - Janosik, J.: Bemerkungen über die Entwicklung des Genitalsystems. Sitzgsber. Akad. Wiss. Wien, Math.-naturwiss. Kl. 99 (1890). - Jaequet, M.: Note sur un cas d'hermaphroditisme incomplet observé chez le Lacerta agilis. Bibl. Anat. 3 (1895). - Jordan, H. E.: The histology of a testis from a case of 
human hermaphroditism with a consideration of the significance of hermaphroditism in relation to the question of sex differentiation. Amer. J. Anat. 31 (1922). Joyet-Lavergne, Ph.: La physico-chimie de la sexualité. Berlin: Gebrüder Bornträger 1930. - Kingsbury, B. F.: The spermatogenesis of Desmognathus fusca. Amer. J. Anat. 1 (1902). - Lantz, L. A.: Hermaphroditisme partiel chez Lacerta saxicola. Bull. Soc. zool. France 48 (1923). - Lillie, F. R.: The free-martin. A study of the action of sex hormones in the foetal life of cattle. J. of exper. Zool. 23 (1917). - The development of the chick. New York: Henry Holt and Company 1919. - The present status of the problem of sex-inversion in the hen. J. of exper. Zool. 48 (1927). - Matthey, R.: Intersexualité chez une Tortue (Emys europaea). C. r. Soc. Biol. Paris 97 (1927). - Mihálkowicz, G. von: Untersuchungen über die Entwicklung des Harn- und Geschlechtsapparates der Amnioten. Internat. Mschr. Anat. u. Histol. 2 (1885). - Morgan, T. H., Bridges, C. B. and Sturtevant, A. H.: The genetics of Drosophila. Bibl. genetica 2 (1925). - Mřsic, W.: Die Spätbefruchtung und deren Einfluß auf Entwicklung und Geschlechtsbildung, experimentell nachgeprüft an der Regenbogenforelle. Arch. mikrosk. Anat. u. Entw.mechan. 98 (1923). - Okkelberg, P.: The early history of the germ cells of the brook lamprey, Entosphenus wilderi Gage, up to and including the period of sex differentiation. J. Morph. a. Physiol. 35 (1921). — Peter, K.: Normentafel zur Entwicklungsgeschichte der Zauneidechse (Lacerta muralis). Normentafeln zur Entwicklungsgeschichte der Wirbeltiere, Heft 4. Jena: Gustav Fischer 1904. - Popoff, N.: L'ovule mâle et le tissue interstitiel du testicule chez les animaux et chez l'homme. Archives de Biol. 34 (1909). - Riddle, 0.: Sex control and known correlations in pigeons. Amer. Naturalist 50 (1916). - Risley, P. L.: Observations on the natural history of the musk turtle, Sternotherus odoratus (Latreucte), Papers Mich. Acad. Sci. 17 (1933). - Contributions on the development of the reproductive system in Sternotherus odoratus (LATREILLE). I. The embryonic origin and migration of the germ cells, 1933. (In press.) - Schmidtgen, 0tto: Die Cloaka und ihre Organe bei den Schildkröten. Zool. Jb., Abt. Anat. 24 (1907). - Sehrader, F.: The Sex Chromosomes. Berlin: Gebrüder Bornträger 1928. - Schrader, F. and Hughes-Sehrader, S.: Haploidy in Metazoa. Quart. Rev. of Biol. 6 (1931). - Sainmont, G.: Recherches relatives à l'organogénèse de testicule et de l'ovaire chez le Chat. Archives de Biol. 22 (1905). - Skrobansky, K.: Beiträge zur Kenntnis der Oogenese bei Säugetieren. Arch. mikrosk. Anat. 62 (1903). - Swift, C. H.: Origin of the definitive sex cells in the female chick and their relationship to the primordial germ cells. Amer. J. Anat. 18 (1915). - Origin of the sex-cords and the definitive spermatogonia in the male chick. Amer. J. Anat. 20 (1916). - Simkins, C. S.: On the origin and migration of the so-called primordial germ cells in the mouse and rat. Acta zool. Arg. 4, 2-3 (1923). - The origin of the germ cells in Trionyx. Amer. J. Anat. 36 (1925). - Simkins, C. S. and Asana, J.: Development of the sex-glands in Calotes. I. Cytology and growth of the gonads prior to hatching. Quart. J. microsc. Sci. 74 (1930). - Swingle, W. W.: Germ cells of anurans. II. An embryological study of sex differentiation in Rana catesbeiana. J. Morph. a. Physiol. 41 (1926). - Waldeyer, W.: Die Geschlechtszellen. O. Hertwigs Handbuch der vergleichenden und experimentellen Entwicklungslehre der Wirbeltiere, Bd. 1, 1 (1906). - Weldon, W. F. R.: On the suprarenal bodies of the Vertebrata. Quart. J. microsc. Sci. 25 (1885). - Winiwarter, H. von et Sainmont, G.: Nouvelles recherches sur l'ovogénèse et l'organogénèse de l'ovaire des Mammifères (Chat). Arch. de Biol. 24 (1909). - Wilson, F. B.: The cell in development and heredity. New York: Macmillan Company 1925. - Witschi, E.: Experimentelle Untersuchung über die Entwicklungsgeschichte der Keimdrüsen der Rana temporaria. Arch. mikrosk. Anat. 85 (1914 a). - Studien über die Geschlechtsbestimmung bei Fröschen. Arch. mikrosk. Anat. 86 (1914 b). - Der Hermaphroditismus der Frösche und seine Bedeutung für das Geschlechtsproblem und die Lebre von der 
inneren Sekretion der Keimdrüsen. Arch. Entw.mechan. 49 (1921). - Die Entwicklung der Keimzellen der Rana temporaria L. I. Urkeimzellen und Spermatogenese. Z. Zellenlehre 1, 4 (1924). - Sex reversal in parabiotic twins of the American wood frog Rana sylvatica. Biol. Bull. Mar. biol. Labor. Wood's Hole 52 (1927). Studies on sex differentiation and sex determination in amphibians. I. Development and sexual differentiation of the gonads of Rana sylvatica. J. of exper. Zool. 52 (1929 a). - Studies on sex differentiation and sex determination in amphibians. II. Sex reversal in female tadpoles of Rana sylvatica following the application of high temperature. J. of exper. Zool. $52(1929 \mathrm{~b})$. - Studies on sex differentiation and sex determination in amphibians. III. Rudimentary hermaphroditism and Y chromosome in Rana temporaria. J. of exper. Zool. 54 (1929 c). Studies on sex differentiation and sex determination in amphibians. IV. The geographical distribution of the sex races of the European grass frog (Rana temporaria L.). A contribution to the problem of the evolution of sex. J. of exper. Zool. 56 (1930). - Studies on sex differentiation and sex determination in amphibians. V. Range of the cortex-medulla antagonism in parabiotic twins of Ranidae and Hylidae. J. of exper. Zool. 58 (1931). - Witschi, E. and MeCurdy, H. M.: The free-martin effect in experimental parabiotic twins of Triturus torosus. Proc. Soc. exper. Biol. a. Med. 26 (1929). - Zawadowsky, M.: Bisexual nature of the hen and experimental hermaphroditism in hens. Trans. Labor. exper. Biol., Zoopark Moscow 2 (1926). 